\title{
Yttrium Aluminum Garnet Fibers from Metalloorganic Precursors
}

\author{
Yin Liu, ${ }^{*}$ Zhi-Fan Zhang, John Halloran, ${ }^{*}$ and Richard M. Laine ${ }^{*}$ \\ Departments of Materials Science and Engineering, Chemistry, and the \\ Macromolecular Science and Engineering Center, University of Michigan,
} Ann Arbor, Michigan 48109-2136

\begin{abstract}
Mixtures of yttrium acetate hydrate $\left(\mathrm{Y}\left(\mathrm{O}_{2} \mathrm{CCH}_{3}\right)_{3} \cdot 4 \mathrm{H}_{2} \mathrm{O}\right)$ and aluminum formate hydrate $\left(\mathrm{Al}\left(\mathrm{O}_{2} \mathrm{CH}\right)_{3} \cdot 3 \mathrm{H}_{2} \mathrm{O}\right.$ in $\left.\mathrm{H}_{2} \mathrm{O}\right)$ or yttrium isobutyrate $\left(\mathrm{Y}\left[\mathrm{O}_{2} \mathrm{CCH}\left(\mathrm{CH}_{3}\right)_{2}\right]_{3}\right)$ and aluminum isobutyrate $\left(\mathrm{AI}\left[\mathrm{O}_{2} \mathrm{CCH}\left(\mathrm{CH}_{3}\right)_{2}\right]_{3}\right)$ in tetrahydrofuran were used as precursors to process yttrium aluminum garnet (YAG, $\mathrm{Al}_{5} \mathrm{Y}_{3} \mathrm{O}_{12}$ ) fibers. The pyrolytic decomposition patterns of $\mathrm{Al}\left(\mathrm{O}_{2} \mathrm{CH}\right)_{3} \cdot 3 \mathrm{H}_{2} \mathrm{O}, \mathrm{Y}\left(\mathrm{O}_{2} \mathrm{CCH}_{3}\right)_{3} \cdot 4 \mathrm{H}_{2} \mathrm{O}$, and a $\left[3 \mathrm{Y}\left(\mathrm{O}_{2} \mathrm{CCH}_{3}\right)_{3} \cdot 4 \mathrm{H}_{2} \mathrm{O} / 5 \mathrm{Al}\left(\mathrm{O}_{2} \mathrm{CH}\right)_{3} \cdot 3 \mathrm{H}_{2} \mathrm{O}\right] \mathrm{YAG}$ stoichiometry mixture were assessed by heating samples to selected temperatures and characterizing the products by thermogravimetric analysis, differential thermal analysis, $X$-ray diffractometry, and Fourier transform infrared spectroscopy. The YAG acetate/formate precursor decomposes to an amorphous intermediate at temperatures $>400^{\circ} \mathrm{C}$ and crystallizes (at $\sim 800^{\circ} \mathrm{C}$ ) to phase-pure YAG with a ceramic yield of $40 \%$ at $1000^{\circ} \mathrm{C}$. YAG isobutyrate precursor fibers were extruded or hand drawn. YAG acetate/formate precursor fibers were formed using a commercial extruder. The pyrolysis behavior of both precursor fibers was studied to identify the best pyrolysis conditions for producing dense, defect-free ceramic fibers. Only thin (diameter of $<30 \mu \mathrm{m})$ precursor fibers could be processed to dense, defect-free, thin YAG fibers (diameter of $<20 \mu \mathrm{m}$ ). For the YAG isobutyrate precursor, crack-free crystalline YAG fibers (diameter of $\sim 7 \mu \mathrm{m}$ ) were obtained at $1000^{\circ} \mathrm{C}$. For YAG acetate/formate precursor fibers, dwell times of $2 \mathrm{~h}$ at temperatures of $400^{\circ}$ and $900^{\circ} \mathrm{C}$ were necessary to process fully dense, defect-free ceramic fibers. Heating the resulting $900^{\circ} \mathrm{C}$ fibers (at a rate of $30^{\circ} \mathrm{C} / \mathrm{min}$ ) to $1570^{\circ}-1650^{\circ} \mathrm{C}$ gave dense fibers with grain sizes of $0.7-3.2 \mu \mathrm{m}$ and bend strengths of up to $1.7 \pm 0.2 \mathrm{GPa}$ (for fibers that had a diameter of $\sim 10 \mu \mathrm{m}$ and had undergone sintering at $\left.1600^{\circ} \mathrm{C}\right)$.
\end{abstract}

\section{Introduction}

Y TTRIUM aluminum garnet (YAG or $\mathrm{Al}_{5} \mathrm{Y}_{3} \mathrm{O}_{12}$ ) exhibits high strength and low creep rates at high temperatures $\left(>1000^{\circ} \mathrm{C}\right)$ and, thus, offers potential for high-temperature structural applications. ${ }^{1-4}$ In particular, YAG fibers may be of use for reinforcing ceramic-matrix composites (CMCs). ${ }^{5}$ In fiber-reinforced CMCs, thin fibers $(<20 \mu \mathrm{m})$ are desired because of their high strength, flexibility, and weavability. ${ }^{6,7} \mathrm{Un}-$ fortunately, traditional ceramic processing methods (e.g., powder and melt processing) are usually not amenable to processing thin fibers $(<20 \mu \mathrm{m}$ in diameter $) .{ }^{1,6-10}$ Thus, chemical-processing approaches to ceramic fibers are now widely

B. Dunn-contributing editor

Manuscript No. 191263. Received January 22, 1997; approved June 6, 1997.

Supported by the U.S. Air Force Wright Laboratory, Wright-Patterson Air Force Base (Wright-Patterson AFB, OH) through Contract Nos. F33615-91-C-5650 and FQ8671-9700732. Partially supported by the U.S. Office of Naval Research.

"Member, American Ceramic Society. used. ${ }^{1,11-14}$ For example, commercial Nicalon ${ }^{\text {(1WI }}(10-12 \mu \mathrm{m}$ in diameter; Nippon Carbon, Tokyo, Japan) and Tyranno ${ }^{\text {TiM }}(8-10$ $\mu \mathrm{m}$ in diameter; Ube Industries, Yamaguchi, Japan) Si-C-O composite fibers are produced from polycarbosilane precursors. ${ }^{8,15}$ Similarly, various commercial oxide fibers (most based on alumina $\left(\mathrm{Al}_{2} \mathrm{O}_{3}\right)$ are produced using chemicalprocessing approaches. For example, Saffil ${ }^{(\mathbb{N O}} \mathrm{Al}_{2} \mathrm{O}_{3}$ fibers (diameter of $\sim 3 \mu \mathrm{m}, 5 \%$ silica $\left(\mathrm{SiO}_{2}\right)$; ICI, Runcorn, U.K.) are produced from $\mathrm{AlCl}_{3}$ or aluminum acetate/polysiloxane precursors, ${ }^{16}$ and Sumika Alumina ${ }^{\mathbb{T M}}$ fibers (diameter of $\sim 17 \mu \mathrm{m}$, $50 \% \mathrm{SiO}_{2}$; Sumitomo Chemicals, Tokyo, Japan) are produced from alkyl-substituted polyaluminoxane/silicate ester precursors. ${ }^{17}$ Both fiber microstructures are reported to consist of $\mathrm{Al}_{2} \mathrm{O}_{3}$ nanocrystals in an amorphous aluminosilicate matrix. The presence of an amorphous phase reduces the fiber tensile modulus, melting temperature, and creep resistance. ${ }^{16}$

The Nextel (The 3M Co., St. Paul, MN) series of $\mathrm{Al}_{2} \mathrm{O}_{3}$ based fibers $(312,440,610$, and 720 , diameters of $10-12 \mu \mathrm{m})$ are made using aluminum monoacetate or formoacetate/silica hydrosol precursors. ${ }^{18-22}$ The $3 \mathrm{M}$ patents describe methods of producing $\mathrm{Al}_{2} \mathrm{O}_{3}$ precursor fibers from spinnable solutions that consist of high concentrations of aluminum monoacetate (or aluminum formoacetate), lactic acid (or DMF), silica hydrosol, and small amounts of boric acid $\left(\mathrm{H}_{3} \mathrm{BO}_{3}\right)(\sim 2 \mathrm{wt} \%)$ or a hydrous iron polymer solution $(\sim 0.6 \mathrm{wt} \% \mathrm{Fe})$ in $\mathrm{H}_{2} \mathrm{O} .{ }^{19,20}$ The extruded precursor fibers, on pyrolysis to temperatures $>1000^{\circ} \mathrm{C}$, exhibit composite microstructures that contain mixtures of microcrystalline (nanocrystalline) $\mathrm{Al}_{2} \mathrm{O}_{3}$ with mullite, silica-boria $\left(\mathrm{SiO}_{2}-\mathrm{B}_{2} \mathrm{O}_{3}\right)$, or aluminosilicates. The composite fibers exhibit melting points that are lower than that of $\mathrm{Al}_{2} \mathrm{O}_{3}$ because of the presence of lower melting phases, such as $\mathrm{SiO}_{2}$, $\mathrm{B}_{2} \mathrm{O}_{3}$, or mullite. For example, Nextel 440 (70 wt $\% \mathrm{Al}_{2} \mathrm{O}_{3} / 28$ wt $\% \mathrm{SiO}_{2} / 2 \mathrm{wt} \% \mathrm{~B}_{2} \mathrm{O}_{3}$ ) melts at a temperature of $\sim 1700^{\circ} \mathrm{C}$, which is lower than that of $\mathrm{Al}_{2} \mathrm{O}_{3}\left(2054^{\circ} \mathrm{C}\right)$. Nextel 610 fibers ( 99 wt $\% \mathrm{Al}_{2} \mathrm{O}_{3} / 0.3 \mathrm{wt} \% \mathrm{SiO}_{2}$, grain size of $\sim 0.1 \mu \mathrm{m}$ ) have a microstructure that consists of $\alpha-\mathrm{Al}_{2} \mathrm{O}_{3}$ (major phase) with nanocrystalline mullite. ${ }^{22}$ The presence of lower-melting mullite at $\mathrm{Al}_{2} \mathrm{O}_{3}$ grain boundaries can reduce the hightemperature performance of the fiber. ${ }^{22}$

In addition to $\mathrm{Al}_{2} \mathrm{O}_{3}$ fibers, other oxide fibers, including mullite, zirconia $\left(\mathrm{ZrO}_{2}\right)$, and $\mathrm{SiO}_{2}$, have also been prepared using chemical routes. ${ }^{23}$ Although many polycrystalline oxide fibers have been developed, most of them have a common drawback-i.e., low creep resistance at high temperatures. ${ }^{22}$ The general reason is extremely fine grain sizes $(<0.2 \mu \mathrm{m})$, which, coupled with the presence of a glassy phase, exacerbates creep. Consequently, dense, phase-pure ceramic fibers with larger grain sizes $(0.5-2 \mu \mathrm{m}$ for fibers that are $10-20 \mu \mathrm{m}$ in diameter) are still needed for high-temperature engineering applications.

The choice of $0.5-2.0 \mu \mathrm{m}$ grain sizes is suggested as a means of balancing high-temperature creep resistance with superior mechanical properties at all temperatures. This range of sizes represents a proposed rule of thumb that must be tested, because there are no literature studies on the effects of grain size on creep and mechanical properties for oxide ceramic fibers. Furthermore, because of the high surface-to-volume ratios 
in ceramic fibers, it is not clear that such relationships, developed for monolithic materials, can be applied (see below).

Because YAG offers better high-temperature creep properties than $\mathrm{Al}_{2} \mathrm{O}_{3},{ }^{1-4}$ YAG fibers are potential substitutes for high-temperature engineering applications, as long as the above-mentioned concerns can be resolved. YAG fibers have been produced from the melt by crystal-growth methods. For example, Saphikon $\mathrm{Y}_{3} \mathrm{Al}_{5} \mathrm{O}_{12} / \mathrm{Al}_{2} \mathrm{O}_{3}$ eutectic fibers $(125 \mu \mathrm{m}$ in diameter; Saphikon, Milford, $\mathrm{NH}$ ) are produced using edgedefined film-fed growth (EFG) methods. ${ }^{10,24}$ Single crystalline YAG fibers $(800 \mu \mathrm{m}$ in diameter) have been made using a laser-heated pedestal-growth (LHPG) method. ${ }^{25}$

Phase-pure, polycrystalline YAG fibers have also been made from suspensions of $\mathrm{AlOOH}$ and yttria $\left(\mathrm{Y}_{2} \mathrm{O}_{3}\right)$ colloidal sols. ${ }^{10}$ Fibers with diameters of $\sim 120 \mu \mathrm{m}$ and average grain sizes of $\sim 4 \mu \mathrm{m}$ were shown to offer bend strengths of $\sim 520 \pm 180 \mathrm{MPa}$ and a bend stress relaxation (BSR) parameter of 0.92 $\left(1100^{\circ} \mathrm{C} / 1 \mathrm{~h}\right) .{ }^{10}$ The obtained BSR is a factor of 10 greater than that of all commercially available polycrystalline $\mathrm{Al}_{2} \mathrm{O}_{3}$ fibers. ${ }^{10}$

The above-mentioned large-diameter, inflexible fibers are inconvenient for use in fiber-reinforced CMCs. Furthermore, single-crystal fibers are expensive and difficult to produce in quantity. Chen et al. ${ }^{26}$ were able to produce thinner YAG fibers (diameters of $15-30 \mu \mathrm{m}$, grain sizes of $1.5 \mu \mathrm{m}$, and a BSR parameter of 0.95 at $1100^{\circ} \mathrm{C} / 1 \mathrm{~h}$ ) via sol-gel processing; however, small amounts of a second phase were added as a sintering aid, to improve fiber integrity. ${ }^{26}$ Thus, phase-pure, fully dense, flexible YAG fibers still remain a viable processing target.

For this purpose, we recently described the use of yttrium and aluminum isobutyrates to synthesize YAG powders. ${ }^{1}$ YAG fibers were also accessible ${ }^{27}$ however, this process required an inert environment (nitrogen gas or argon), because of the high moisture sensitivity and organic solvents (tetrahydrofuran (THF) and toluene) in aluminum isobutyrate. To simplify the process, we considered precursors that were less sensitive to air or moisture and were $\mathrm{H}_{2} \mathrm{O}$ soluble. Yttrium acetate hydrate $\left(\mathrm{Y}\left(\mathrm{O}_{2} \mathrm{CCH}_{3}\right)_{3} \cdot 4 \mathrm{H}_{2} \mathrm{O}\right)$ and aluminum formate hydrate $\left(\mathrm{Al}\left(\mathrm{O}_{2} \mathrm{CH}\right)_{3} \cdot 3 \mathrm{H}_{2} \mathrm{O}\right)$ are both stable in air, dissolve in $\mathrm{H}_{2} \mathrm{O}$, and offer potential as starting materials for the synthesis of YAG fibers. In this paper, we describe (i) the reactivity patterns of $\mathrm{Al}\left(\mathrm{O}_{2} \mathrm{CH}\right)_{3} \cdot 3 \mathrm{H}_{2} \mathrm{O}, \mathrm{Y}\left(\mathrm{O}_{2} \mathrm{CCH}_{3}\right)_{3} \cdot 4 \mathrm{H}_{2} \mathrm{O}$, and 5:3 (Al:Y) stoichiometric mixtures of these compounds (YAG precursor) during their pyrolytic transformation to phase-pure $\mathrm{Al}_{2} \mathrm{O}_{3}, \mathrm{Y}_{2} \mathrm{O}_{3}$, and YAG, respectively; (ii) studies on fiber processing; and (iii) initial studies on the mechanical properties of YAG fibers from the formate/acetate precursor.

\section{Experimental Procedure}

\section{(1) General Procedure}

Aluminum tri(sec-butoxide) was purchased from Chattem Chemicals (Chattanooga, TN) and was used as received. Isobutyric acid (99\%) was purchased from Pfaltz and Bauer (Waterbury, CT). Yttrium acetate hydrate $(99.9 \%)\left(\mathrm{Y}_{2} \mathrm{O}_{2} \mathrm{CCH}_{3}\right)_{3}$. $x \mathrm{H}_{2} \mathrm{O}$ ) was purchased from Johnson Matthey Co. (Ward Hill, MA), and ethylene glycol (99\%) was purchased from J. T. Baker (Phillipsburg, NJ). Formic acid (95\%-97\%) was purchased from Aldrich Chemical Co. (Milwaukee, WI). All the experiments were conducted in air.

\section{(2) Synthesis and Characterization of YAG Precursor}

(A) Synthesis of Aluminum Formate Hydrate $\mathrm{Al}\left(\mathrm{O}_{2} \mathrm{CH}\right)_{3}$. $3 \mathrm{H}_{2} \mathrm{O} \quad(\mathrm{FW}=216.081)$ : Aluminum tri(sec-butoxide), $\mathrm{Al}(\mathrm{OsBu})_{3}$, is $11 \mathrm{wt} \%$ aluminum (by thermogravimetric analysis (TGA)). In air, $75.09 \mathrm{~g}(306 \mathrm{mmol})$ of $\mathrm{Al}(\mathrm{OsBu})_{3}$ was added to a $1000 \mathrm{~mL}$ beaker; $200.0 \mathrm{~mL}$ of $\mathrm{H}_{2} \mathrm{O}$ (deionized, $11.11 \mathrm{~mol}$, 12 equiv) was added to this material. The mixture gelled immediately as $\mathrm{Al}(\mathrm{OH})_{3} \cdot 3 \mathrm{H}_{2} \mathrm{O}$ formed. Then, $60.0 \mathrm{~g}(1.30 \mathrm{~mol}$, 1.42 equiv) of formic acid was added, partially dissolving the white gel. Another $300 \mathrm{~mL}$ of $\mathrm{H}_{2} \mathrm{O}$ was added, and the mixture was heated, with stirring, to boiling. After $1 \mathrm{~h}$, the white gel dissolved to a cloudy liquid. Boiling was continued (with stirring) to reduce the volume to $\sim 100 \mathrm{~mL}$. The temperature was then reduced to $60^{\circ} \mathrm{C}$, to slow the evaporation rate. The beaker was covered with a watch glass to prevent contamination during evaporation. When the mixture became a wet white powder, it was further dried (drierite, $\mathrm{SiO}_{2}$ gel) in a desiccator for $2 \mathrm{~d}$. The yield was $65.9 \mathrm{~g}\left(306 \mathrm{mmol}\right.$ of $\left.\mathrm{Al}\left(\mathrm{O}_{2} \mathrm{CH}\right)_{3} \cdot 3 \mathrm{H}_{2} \mathrm{O}\right)$, which is a $100 \%$ yield, based on the $\mathrm{Al}(\mathrm{OsBu})_{3}$ that was consumed. The product was soluble in boiling water and gave a TGA $\left(1000^{\circ} \mathrm{C}\right)$ ceramic yield of $23.6 \mathrm{wt} \%$ (theoretical yield is $23.6 \mathrm{wt} \%)$.

(B) Purification of Yttrium Acetate Hydrate, $\left.\mathrm{Y}_{(} \mathrm{O}_{2} \mathrm{CCH}_{3}\right)_{3}$. $4 \mathrm{H}_{2} \mathrm{O} \quad(\mathrm{FW}=338.10)$ : Energy-dispersive spectroscopy (EDS) analysis showed trace amounts of chlorine and calcium in the purchased yttrium acetate. Therefore, $65 \mathrm{~g}$ of material was recrystallized from $500 \mathrm{~mL}$ of hot $\mathrm{H}_{2} \mathrm{O}\left(100^{\circ} \mathrm{C}\right)$ and then filtered through coarse filter paper (P8, Fisher-brand, Fisher Scientific Hampton, NH). Evaporation at $100^{\circ} \mathrm{C}$ to $\sim 150 \mathrm{~mL}$ gave a supersaturated solution (precipitates appeared) from which $56.4 \mathrm{~g}$ of crystalline product $\left(87 \%\right.$ yield, dried at $20^{\circ} \mathrm{C} / 2$ $\mathrm{d} /$ air) was recovered on cooling. No chlorine and calcium impurities were detected. The TGA ceramic yield was $33.5 \mathrm{wt} \%$ (theoretical yield is $33.4 \%$ ).

(C) Preparation of YAG Precursor Solution: A 3:5 stoichiometric precursor solution, $3 \mathrm{Y}_{(}\left(\mathrm{O}_{2} \mathrm{CCH}_{3}\right)_{3}: 5 \mathrm{Al}\left(\mathrm{O}_{2} \mathrm{CH}\right)_{3}$, was prepared by dissolving $11.63 \mathrm{~g}(34.4 \mathrm{mmol})$ of $\mathrm{Y}\left(\mathrm{O}_{2} \mathrm{CCH}_{3}\right)_{3} \cdot 4 \mathrm{H}_{2} \mathrm{O}$ and $12.40 \mathrm{~g}(57.4 \mathrm{mmol}) \mathrm{Al}\left(\mathrm{O}_{2} \mathrm{CH}\right)_{3} \cdot$ $3 \mathrm{H}_{2} \mathrm{O}$ in $350 \mathrm{~mL}$ of $\mathrm{H}_{2} \mathrm{O}$ at $100^{\circ} \mathrm{C}$ in a $400 \mathrm{~mL}$ beaker. Formic acid ( $\sim 6 \mathrm{~g})$, ethylene glycol (4 g), and isobutyric acid (2 g) were added to stabilize the solution. The resulting solution was evaporated to reduce the volume to $\sim 80 \mathrm{~mL}$ and then transferred to a rotary evaporator (Model RE-111, Brinkmann Instruments, Westbury, NY) to further reduce the volume until the viscosity was suitable for hand-drawing fibers (final volume of $\sim 30 \mathrm{~mL}$, TGA ceramic yield of $28 \%$ ). Approximately $15 \mathrm{~mL}$ of YAG precursor solution was transferred to a $50 \mathrm{~mL}$ schlenk flask, then connected to a vacuum line and vacuum dried at $100^{\circ} \mathrm{C}(\sim 0.75$ torr $(\sim 100 \mathrm{~Pa}))$ for $2 \mathrm{~h}$. The dried precursor gave a TGA ceramic yield of $40.5 \%$ at $1000^{\circ} \mathrm{C}$. After grinding in an $\mathrm{Al}_{2} \mathrm{O}_{3}$ mortar and pestle in air, the precursor was ready for bulk material studies.

(D) Density Measurements: Density measurements were used to establish the theoretical volume changes that are expected during the conversion from precursor to ceramic. Vacuum-dried, ground YAG precursor powders $(\sim 0.50 \mathrm{~g})$ were pressed into disks that were $12.8 \mathrm{~mm}$ in diameter, using an applied pressure of $255 \mathrm{MPa}$ for $15 \mathrm{~s}$. The carboxylate complexes are assumed to deform plastically. Thus, the resulting pellet is assumed to be almost $100 \%$ dense. Optical microscopy suggests a fully dense material without visible porosity. ${ }^{7}$ The dimensions of compacted pellets were measured (using calipers) to determine the densities. The average pellet dimensions were $12.86 \mathrm{~mm} \times 2.42 \mathrm{~mm}$, with a density of $1.5 \mathrm{~g} / \mathrm{cm}^{3}$.

\section{(3) Pyrolysis and Characterization of the Bulk Precursor}

(A) Pyrolysis Studies: Ground samples $(\sim 1 \mathrm{~g})$ of $\mathrm{Al}\left(\mathrm{O}_{2} \mathrm{CH}\right)_{3} \cdot 3 \mathrm{H}_{2} \mathrm{O}, \mathrm{Y}\left(\mathrm{O}_{2} \mathrm{CCH}_{3}\right)_{3} \cdot 4 \mathrm{H}_{2} \mathrm{O}$, and the YAG precursor were placed in separate $\mathrm{Al}_{2} \mathrm{O}_{3}$ boats and heated in dry air at a rate of $10^{\circ} \mathrm{C} / \mathrm{min}$ to selected temperatures, followed by a holding period of $2 \mathrm{~h}$. Pyrolyses at temperatures $<1000^{\circ} \mathrm{C}$ were conducted in a furnace (Type 6000, Thermolyne, Dubuque, IA) in flowing air $\left(100 \mathrm{~cm}^{3} / \mathrm{min}\right)$ that was equipped with a programmable temperature controller (Model 818P, Eurotherm, Northing, U.K.). Pyrolyses at $1400^{\circ} \mathrm{C}$ were conducted in another furnace (Model 51314, Lindberg, Watertown, WI) equipped with a controller (Model 59246-P, Lindberg).

(B) Thermogravimetric Analysis (TGA): TGA studies were performed using a thermal analysis instrument (Model Hi-Res TGA 2950, TA Instruments, New Castle, DE). The samples were loaded on a platinum sample pan. The TGA was 
ramped at a rate of $10^{\circ} \mathrm{C} / \mathrm{min}$ to $1000^{\circ} \mathrm{C}$ at the "High-Res 4 ", setting, with a nitrogen-gas balance flow of $40 \mathrm{~cm}^{3} / \mathrm{min}$ and an air-purge flow of $60 \mathrm{~cm}^{3} / \mathrm{min}$.

(C) Differential Thermal Analysis (DTA): DTA experiments were conducted using a differential scanning calorimeter (Model DSC 2910, TA Instruments). DTA samples (10-20 mg) were loaded into a platinum crucible and heated at the same rate as the corresponding TGA Hi-Res sample rate, to $1500^{\circ} \mathrm{C}$ in dry air at a flow rate of $50 \mathrm{~cm}^{3} / \mathrm{min}$. The DTA reference was $\alpha-\mathrm{Al}_{2} \mathrm{O}_{3}$ (Aluminum Co. of America, Pittsburgh, PA).

(D) Diffuse Reflectance Infrared Fourier Transform Spectroscopy (DRIFTS): DRIFTS studies were performed using a Fourier transform infrared spectroscopy (FTIR) spectrometer (Mattson Galaxy Series FTIR-3000, Mattson Instruments, Madison, WI). Optical-grade potassium bromide ( $\mathrm{KBr}$ ) crystal from International Crystal Laboratories (Garfield, NJ) was ground and used as the background. The experimental details have been described. ${ }^{1}$

(E) X-ray Diffractometry (XRD) Studies of Precursor Pyrolysis Products: The pyrolytic transformation of the precursors to crystalline products, as a function of processing temperature, was followed by X-ray diffractometry (XRD) using a rotating anode goniometer (Rigaku Denki Co., Tokyo, Japan). Samples (40-80 mg) were prepared using the same procedures as for the DRIFTS samples. The powders were then loaded into $\mathrm{X}$-ray sample holders (glass plates) for data collection. The working voltage and current were $40 \mathrm{kV}$ and $100 \mathrm{~mA}$, respectively. $\mathrm{CuK \alpha}(\lambda=1.54 \AA)$ radiation with a nickel filter was used. Scans were continuous from $5^{\circ}-80^{\circ} 2 \theta$, with a step scan of $10^{\circ} 2 \theta / \mathrm{min}$ and increments of $0.05^{\circ} 2 \theta$. Products (peak positions and relative intensities) were characterized by comparison with standard $\mathrm{JCPDS}^{\dagger}$ files.

\section{(4) Fiber Studies}

(A) Fiber Drawing and Extrusion: Precursor fibers were both hand drawn and extruded. For hand-drawn fibers, a small spatula was dipped into the viscous solution and withdrawn. The resulting fibers were suspended from a wooden framework $(100 \mathrm{~mm} \times 100 \mathrm{~mm})$ and left to air dry. In this case, green fibers $\leq 20 \mu \mathrm{m}$ in diameter and $200 \mathrm{~mm}$ in length were obtained.

Fibers were also extruded in air using an extruder (Bradford University Research, Bradford, U.K.). The extrusion spinneret diameter was $80 \mu \mathrm{m}$. Typically, $10 \mathrm{~mL}$ of precursor solution (ceramic yield of $27.9 \mathrm{wt} \%$ ) was loaded into the chamber of the extruder. An extrusion load of $300-400 \mathrm{~kg}$ was applied to the piston to extrude fibers, with the extrusion-ram speed set at $0.05-0.15 \mathrm{~mm} / \mathrm{min}$. A rotating fiber takeup reel that was 250 $\mathrm{mm}$ in diameter and located $1 \mathrm{~m}$ below the spinneret allowed fiber drawing. Thinner or thicker fibers could be collected as a function of the takeup reel rotation speed, which could be varied from $0-10 \mathrm{rpm}$. The thinnest continuous fibers obtained were $\sim 20 \mu \mathrm{m}$ dia.

(B) Pyrolysis Studies of Fibers: All the $\mathrm{Al}\left(\mathrm{O}_{2} \mathrm{CH}\right)_{3} \cdot \mathrm{H}_{2} \mathrm{O}$ and $\mathrm{Y}\left(\mathrm{O}_{2} \mathrm{CCH}_{3}\right)_{3} \cdot 4 \mathrm{H}_{2} \mathrm{O}$ precursor fibers were dried at $100^{\circ} \mathrm{C}$ for $2 \mathrm{~h}$, to remove the solvent, and then heated at a rate of $1^{\circ} \mathrm{C} / \mathrm{min}$ to $400^{\circ} \mathrm{C}$ and held at that temperature for $2 \mathrm{~h}$. The same Lindberg furnace that was used for bulk material studies was used for the high-temperature pyrolyses. All pyrolyses were conducted in air. Several heat-treatment schedules were studied: (i) heat treatment to remove carbonate by pyrolyzing fibers at $900^{\circ}$ or $1000^{\circ} \mathrm{C}$ and holding them at that temperature for $2 \mathrm{~h}$; (ii) different heating rates, such as $15^{\circ} \mathrm{C} / \mathrm{min}$ and $30^{\circ} \mathrm{C} /$ min, for sintering; and (iii) sintering temperatures of $1400^{\circ}$, $1500^{\circ}, 1550^{\circ}, 1570^{\circ}, 1600^{\circ}$, and $1650^{\circ} \mathrm{C}$. Also, a batch of fibers were heat treated at a rate of $20^{\circ} \mathrm{C} / \mathrm{min}$ to $1500^{\circ} \mathrm{C}$ for 2 $\mathrm{h}$ without dwelling at a temperature of $400^{\circ} \mathrm{C}$ for $2 \mathrm{~h}$.

Joint Committee on Powder Diffraction Standards, Swarthmore, PA (now International Center for Diffraction Data (ICDD), Newtowne Square, PA).
(C) Scanning Electron Microscopy (SEM): Green and pyrolyzed precursor fibers were characterized using a scanning electron microscopy (SEM) microscope (Model S800, Hitachi, Tokyo, Japan) that was operating at $5 \mathrm{keV}$. SEM samples were prepared by mounting fibers (3-5 $\mathrm{mm}$ in length) on an aluminum stub using carbon paste. The fibers were sputter coated with $\sim 0.1 \mu \mathrm{m} \mathrm{Au} / \mathrm{Pd}$ to improve the conductivity.

(D) Fiber Bend Tests: The strength of pyrolyzed fibers was evaluated using a "bending test," as described in detail elsewhere, ${ }^{28,29}$ this was done by forcing a YAG fiber sample to conform to a certain radius of curvature by looping it around drill bits or steel wires of decreasing diameters until the fiber failed. The diameters of the drill bits and wires that were used ranged from $2.5 \mathrm{~mm}$ to $0.5 \mathrm{~mm}$. The fracture cross section of the broken fiber was then assessed by SEM, and the shortest distance from the centroidal axis to the surface of the fiber was recorded. The bend strength $(\sigma)$ was then calculated using the relation

$$
\sigma=\frac{E z}{\rho}
$$

where $E$ is the elastic modulus (the value that was used is 280 $\mathrm{GPa}){ }^{28} z$ the shortest distance from the centroidal axis to the surface of the fiber, and $\rho$ the radius of curvature at which the fiber breaks.

\section{Results and Discussion}

In the following sections, we discuss (i) the synthesis and characterization of $\mathrm{Al}\left(\mathrm{O}_{2} \mathrm{CH}\right)_{3} \cdot 3 \mathrm{H}_{2} \mathrm{O}, \mathrm{Y}\left(\mathrm{O}_{2} \mathrm{CCH}_{3}\right)_{3} \cdot 4 \mathrm{H}_{2} \mathrm{O}$, and a formate/acetate YAG precursor, (ii) bulk pyrolysis decomposition patterns for the individual carboxylates and the YAG precursor, and (iii) preliminary studies on processing fibers from isobutyrate and formate/acetate precursors.

\section{(1) Synthesis of $\mathrm{Al}\left(\mathrm{O}_{2} \mathrm{CH}\right)_{3} \cdot 3 \mathrm{H}_{2} \mathrm{O}$}

Aluminum formate hydrate was synthesized via the following reactions: $:^{30,31}$

$$
\begin{aligned}
& \mathrm{Al}\left(\mathrm{OCH}_{3} \mathrm{CHCH}_{2} \mathrm{CH}_{3}\right)_{3}+3 \mathrm{H}_{2} \mathrm{O} \stackrel{\text { room temp. }}{\longrightarrow} \mathrm{Al}(\mathrm{OH})_{3} \\
& \quad+3 \mathrm{HOCH}_{3} \mathrm{CHCH}_{2} \mathrm{CH}_{3} \\
& \mathrm{Al}(\mathrm{OH})_{3}+3 \mathrm{HOOCH} \stackrel{100^{\circ} \mathrm{C}}{\longrightarrow} \mathrm{Al}\left(\mathrm{O}_{2} \mathrm{CH}\right)_{3}+3 \mathrm{H}_{2} \mathrm{O}
\end{aligned}
$$

Reaction (2) provides different hydrate products, depending on the temperature at which water is removed, as discussed by Kwon $^{30}$ and Chaplygina et al. ${ }^{31}$ When the final evaporation temperature is $105^{\circ} \mathrm{C}$, the product is $\mathrm{Al}(\mathrm{OH})\left(\mathrm{O}_{2} \mathrm{CH}\right)_{2} \cdot \mathrm{H}_{2} \mathrm{O}$, which is insoluble in $\mathrm{H}_{2} \mathrm{O}$, even at $100^{\circ} \mathrm{C} .{ }^{30} \mathrm{Al}\left(\mathrm{O}_{2} \mathrm{CH}\right)_{3} \cdot 3 \mathrm{H}_{2} \mathrm{O}$, which is obtained at $\sim 65^{\circ} \mathrm{C}$, dissolves slightly in $\mathrm{H}_{2} \mathrm{O} .{ }^{31}$ $\mathrm{Al}\left(\mathrm{O}_{2} \mathrm{CH}\right)_{3} \cdot 4 \mathrm{H}_{2} \mathrm{O}$, which is obtained at room temperature, dissolves in $\mathrm{H}_{2} \mathrm{O}$ easily. ${ }^{30}$ Anhydrous aluminum formate, $\mathrm{Al}\left(\mathrm{O}_{2} \mathrm{CH}\right)_{3}$, is slightly soluble in cold $\mathrm{H}_{2} \mathrm{O}$ but cannot be obtained via reaction (2). ${ }^{30}$

The $\mathrm{Al}\left(\mathrm{O}_{2} \mathrm{CH}\right)_{3} \cdot 3 \mathrm{H}_{2} \mathrm{O}$ that has been produced here was formed at a temperature of $\sim 60^{\circ} \mathrm{C}$. The product is proposed to be $\mathrm{Al}\left(\mathrm{O}_{2} \mathrm{CH}\right)_{3} \cdot 3 \mathrm{H}_{2} \mathrm{O}$, based on DRIFTS spectra and a found ceramic yield of $23.6 \%$, which is the expected theoretical yield.

\section{(2) Characterization of $\mathrm{Al}\left(\mathrm{O}_{2} \mathrm{CH}\right)_{3} \cdot 3 \mathrm{H}_{2} \mathrm{O}$}

(A) Thermal Analysis: The TGA profile for aluminum formate hydrate decomposition (Fig. 1) shows two regions of mass loss, from $20^{\circ} \mathrm{C}$ to $130^{\circ} \mathrm{C}$ and from $195^{\circ} \mathrm{C}$ to $300^{\circ} \mathrm{C}$, with a final ceramic yield of $23.6 \mathrm{wt} \%$. The first mass loss results in the loss of water and formic acid (reaction (3)): 22

$$
\begin{aligned}
\mathrm{Al}\left(\mathrm{O}_{2} \mathrm{CH}\right)_{3} \cdot 3 \mathrm{H}_{2} \mathrm{O} \stackrel{130^{\circ} \mathrm{C}}{\longrightarrow} & \mathrm{Al}(\mathrm{OH})\left(\mathrm{O}_{2} \mathrm{CH}\right)_{2} \cdot 0.5 \mathrm{H}_{2} \mathrm{O} \\
& +\mathrm{HCOOH} \uparrow+0.5 \mathrm{H}_{2} \mathrm{O} \uparrow
\end{aligned}
$$

The ceramic yield at temperatures $>130^{\circ} \mathrm{C}$ is $35.2 \mathrm{wt} \% \mathrm{Al}_{2} \mathrm{O}_{3}$, which is similar to the theoretical yield for $\mathrm{Al}(\mathrm{OH})\left(\mathrm{O}_{2} \mathrm{CH}\right)_{2}$. 


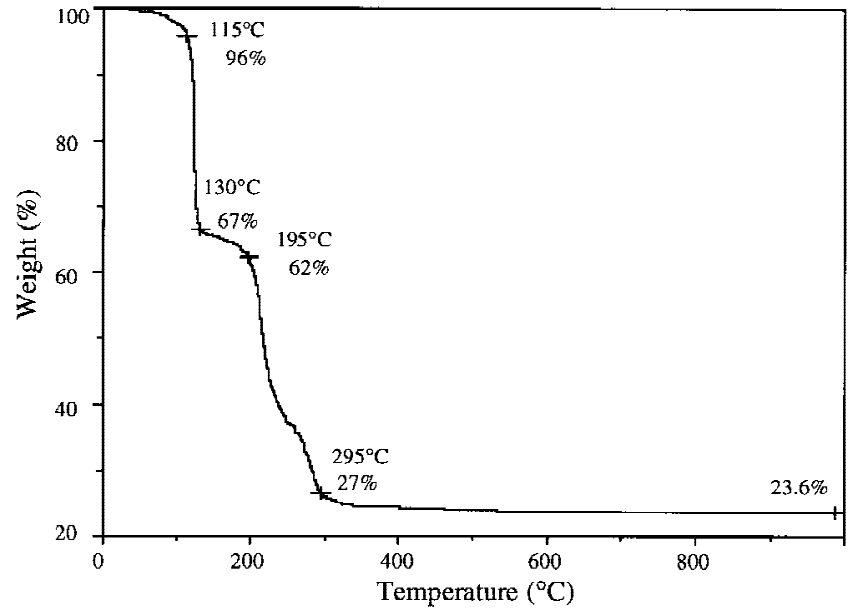

Fig. 1. TGA of $\mathrm{Al}\left(\mathrm{O}_{2} \mathrm{CH}\right)_{3} \cdot 3 \mathrm{H}_{2} \mathrm{O}$ in air.

$\left.0.5 \mathrm{H}_{2} \mathrm{O}(35.6 \mathrm{wt} \%) . \mathrm{Al}(\mathrm{OH}) \mathrm{O}_{2} \mathrm{CH}\right)_{2} \cdot 0.5 \mathrm{H}_{2} \mathrm{O}$ formation is suggested by the DRIFTS studies below. At higher temperatures, $\mathrm{Al}(\mathrm{OH})\left(\mathrm{O}_{2} \mathrm{CH}\right)_{2} \cdot 0.5 \mathrm{H}_{2} \mathrm{O}$ transforms to $\mathrm{Al}_{2} \mathrm{O}_{3}:{ }^{30}$

$$
\begin{aligned}
12 \mathrm{Al}(\mathrm{OH})\left(\mathrm{O}_{2} \mathrm{CH}\right)_{2} \cdot 0.5 \mathrm{H}_{2} \mathrm{O} \stackrel{340^{\circ} \mathrm{C}}{\longrightarrow} 6 \mathrm{Al}_{2} \mathrm{O}_{3} \\
+5 \mathrm{HCOOH} \uparrow+19 \mathrm{CO} \uparrow+8.5 \mathrm{H}_{2} \mathrm{O} \uparrow
\end{aligned}
$$

Several intermediate decomposition products are proposed to form: ${ }^{32}$

$$
\begin{aligned}
\mathrm{Al}(\mathrm{OH})\left(\mathrm{O}_{2} \mathrm{CH}\right)_{2} & \stackrel{200^{\circ} \mathrm{C}}{\longrightarrow} \mathrm{Al}_{2} \mathrm{O}\left(\mathrm{O}_{2} \mathrm{CH}\right)_{4} \stackrel{270^{\circ} \mathrm{C}}{\longrightarrow} \\
\mathrm{AlO}\left(\mathrm{O}_{2} \mathrm{CH}\right) & \stackrel{340^{\circ} \mathrm{C}}{\longrightarrow} \mathrm{Al}_{2} \mathrm{O}_{3}
\end{aligned}
$$

The differential thermal analysis (DTA) that is shown in Fig. 2 reveals endotherms with maxima at $155^{\circ}$ and $340^{\circ} \mathrm{C}$. The endotherm that is centered at $155^{\circ} \mathrm{C}$ likely corresponds to reaction (3),,$^{30}$ and the endotherm that is centered at $340^{\circ} \mathrm{C}$ likely corresponds to the decomposition of $\mathrm{Al}_{2} \mathrm{O}\left(\mathrm{O}_{2} \mathrm{CH}\right)_{4}$ and $\mathrm{AlO}\left(\mathrm{O}_{2} \mathrm{CH}\right)$ (reaction (5)). ${ }^{31,32}$

DTA of the precursor does not provide clear details about high-temperature phase transformations because the sample size at temperatures $>400^{\circ} \mathrm{C}$ is too small to compare with the reference $\mathrm{Al}_{2} \mathrm{O}_{3}$ (at $400^{\circ} \mathrm{C}, \sim 4 \mathrm{mg}(20 \mathrm{wt} \%$ ) remains). For this reason, a precursor sample was first pyrolyzed to $600^{\circ} \mathrm{C}$ for 2 $\mathrm{h}$. Then, the same quantities of sample and reference $(\sim 20 \mathrm{mg}$

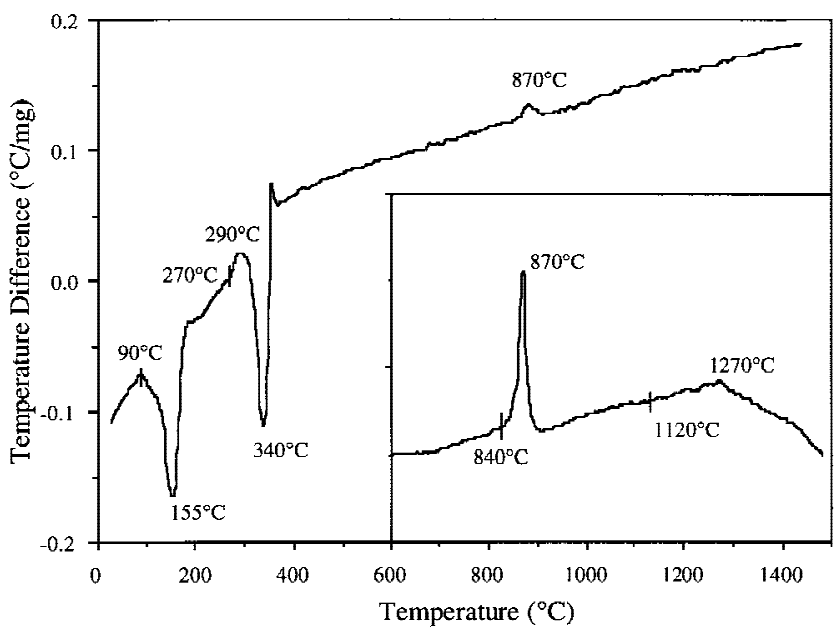

Fig. 2. DTA of $\mathrm{Al}\left(\mathrm{O}_{2} \mathrm{CH}\right)_{3} \cdot 3 \mathrm{H}_{2} \mathrm{O}$ in air; the sample was heated at the same heating rate as TGA for $\mathrm{Al}\left(\mathrm{O}_{2} \mathrm{CH}\right)_{3} \cdot 3 \mathrm{H}_{2} \mathrm{O}$ to $1000^{\circ} \mathrm{C}$, then at $10^{\circ} \mathrm{C} / \mathrm{min}$ to $1500^{\circ} \mathrm{C}$. each) were used to perform the DTA $\left(5^{\circ} \mathrm{C} / \mathrm{min} /\right.$ air $)$ to $1400^{\circ} \mathrm{C}$ to obtain the inset that is shown in Fig. 2. The inset shows two phase transformations: one that starts at $840^{\circ} \mathrm{C}$ and another that begins at $1120^{\circ} \mathrm{C}$. The XRD data (Fig. 4) suggest that the $840^{\circ} \mathrm{C}$ exotherm corresponds to the crystallization of $\eta-\mathrm{Al}_{2} \mathrm{O}_{3}$, whereas the $1120^{\circ} \mathrm{C}$ exotherm corresponds to the crystallization of $\alpha-\mathrm{Al}_{2} \mathrm{O}_{3}$. All the intermediate phases are white powders.

(B) DRIFTS: The aluminum formate hydrate spectra that are shown in Fig. 3 (also see Table I) were analyzed and compared with published data. ${ }^{23}$ The broad band at 3600-2300 $\mathrm{cm}^{-1}$ is assigned to $v(\mathrm{O}-\mathrm{H})$ bands in the hydrate water. ${ }^{23}$ The peak at $3500 \mathrm{~cm}^{-1}(v(\mathrm{O}-\mathrm{H}))$ in as-synthesized samples (very weak) and samples that have been pyrolyzed at $125^{\circ} \mathrm{C}$ indicates the presence of hydroxyl groups $(\mathrm{Al}-\mathrm{OH}) .{ }^{31}$ At $125^{\circ} \mathrm{C}$, the spectrum is essentially identical to that reported for $\mathrm{AlOH}\left(\mathrm{O}_{2} \mathrm{CH}\right)_{3} \cdot 0.5 \mathrm{H}_{2} \mathrm{O} .{ }^{31}$

In the $400^{\circ} \mathrm{C}$ spectrum, two slight peaks, at 1615 and 1390 $\mathrm{cm}^{-1}$, indicate the formation of trace amounts of carbonate $\left(\mathrm{CO}_{3}{ }^{2-}\right)$, e.g., $\mathrm{Al}_{2}\left(\mathrm{CO}_{3}\right)_{3}{ }^{1,33}$ The broad absorption bands indicate that the material is amorphous. The absence of a powder diffraction pattern via XRD suggests that the carbonate is either amorphous or of insufficient quantity to be detected ( $<2 \mathrm{wt} \%)$; this is corroborated by the TGA (Fig. 1), which shows a mass loss of $\sim 1 \mathrm{wt} \%$ from $400^{\circ}$ to $1000^{\circ} \mathrm{C}$.

By $900^{\circ} \mathrm{C}$, the carbonate bands disappear, coincident with the appearance of new absorption bands at 575 and $735 \mathrm{~cm}^{-1}$ that correspond to the appearance of $\eta-\mathrm{Al}_{2} \mathrm{O}_{3}$ in the XRD analysis. ${ }^{1}$ In the DRIFTS spectra for samples that have been pyrolyzed at temperatures $>1100^{\circ} \mathrm{C}$, these peaks disappear and new peaks, at $470,490,620$, and $650 \mathrm{~cm}^{-1}$, appear that correspond to the appearance of $\alpha-\mathrm{Al}_{2} \mathrm{O}_{3}$ in the XRD analysis.

(C) XRD Patterns: Figure 4 provides XRD data for $\mathrm{Al}\left(\mathrm{O}_{2} \mathrm{CH}\right)_{3} \cdot 3 \mathrm{H}_{2} \mathrm{O}$ that has been heated $\left(5^{\circ} \mathrm{C} / \mathrm{min} /\right.$ air $)$ to selected temperatures for $2 \mathrm{~h}$. The XRD pattern of the asprocessed sample is crystalline. Although the pattern does not correspond to the diffraction data for $\mathrm{Al}\left(\mathrm{O}_{2} \mathrm{CH}\right)_{3} \cdot 3 \mathrm{H}_{2} \mathrm{O}$, quite similar to the XRD data from Chaplygina et al. ${ }^{31}$

At $125^{\circ} \mathrm{C}$, the material remains crystalline; however, the powder pattern matches the diffraction data for $\mathrm{AlOH}\left(\mathrm{O}_{2} \mathrm{CH}\right)_{2}$. $x \mathrm{H}_{2} \mathrm{O}{ }^{\S}$ The ceramic yield from $125^{\circ} \mathrm{C}(35.2 \mathrm{wt} \%$ vs theoretical, $35.6 \mathrm{wt} \%)$ supports the formation of $\mathrm{AlOH}\left(\mathrm{O}_{2} \mathrm{CH}\right)_{2}$. $0.5 \mathrm{H}_{2} \mathrm{O}$ as an intermediate.

The material becomes amorphous when heated to $400^{\circ} \mathrm{C}$. At $900^{\circ} \mathrm{C}$, the powder pattern reveals low-intensity, broad peaks that are indicative of the partial crystallization of $\eta-\mathrm{Al}_{2} \mathrm{O}_{3} \cdot{ }^{\mathrm{II}} \mathrm{At}$ $1100^{\circ} \mathrm{C}$, as supported by the DTA data (Fig. 2), $\alpha-\mathrm{Al}_{2} \mathrm{O}_{3} \neq$ begins to crystallize. At $1400^{\circ} \mathrm{C}$, a well-defined $\alpha-\mathrm{Al}_{2} \mathrm{O}_{3} \mathrm{XRD}$ pattern results, as indicated by the increasing intensity and the narrowing peak widths.

\section{(3) Characterization of $\mathrm{Y}\left(\mathrm{O}_{2} \mathrm{CCH}_{3}\right)_{3} \cdot 4 \mathrm{H}_{2} \mathrm{O}$}

(A) Thermal Analysis: The $\mathrm{Y}\left(\mathrm{O}_{2} \mathrm{CCH}_{3}\right)_{3} \cdot 4 \mathrm{H}_{2} \mathrm{O}$ that has been used in these studies was recrystallized to remove the calcium and chlorine impurities. Hussein ${ }^{34}$ suggested the following thermal decomposition pattern:

$$
\begin{aligned}
& \mathrm{Y}\left(\mathrm{O}_{2} \mathrm{CCH}_{3}\right)_{3} \cdot 4 \mathrm{H}_{2} \mathrm{O} \stackrel{\sim 500^{\circ} \mathrm{C}}{\longrightarrow} \mathrm{Y}_{2} \mathrm{O}_{3}+\mathrm{Y}_{2}\left(\mathrm{CO}_{3}\right)_{3} \\
& \quad+\text { gases }\left(\mathrm{CO}_{2}, \mathrm{CO}, \mathrm{H}_{2} \mathrm{O}, \mathrm{CH}_{3} \mathrm{COCH}_{3} \text {, other }\right) \uparrow \\
& \mathrm{Y}_{2}\left(\mathrm{CO}_{3}\right)_{3} \stackrel{>600^{\circ} \mathrm{C}}{\longrightarrow} \mathrm{Y}_{2} \mathrm{O}_{3}+\mathrm{CO}_{2} \uparrow
\end{aligned}
$$

The TGA profile (Fig. 5) shows two major mass losses. The first, from ambient to $85^{\circ} \mathrm{C}(\sim 20 \mathrm{wt} \%)$, corresponds to the loss of $\mathrm{H}_{2} \mathrm{O}$. The second mass loss, from $265^{\circ}$ to $340^{\circ} \mathrm{C}(\sim 35 \mathrm{wt} \%)$, corresponds to the decomposition of the complex. At tempera-

JCPDS Powder Diffraction File Card No. 38-655
SJCPDS Powder Diffraction File Card No. 37-771

IJCPDS Powder Diffraction File Card No. 16-394.

JCPDS Powder Diffraction File Card No. 10-173. 


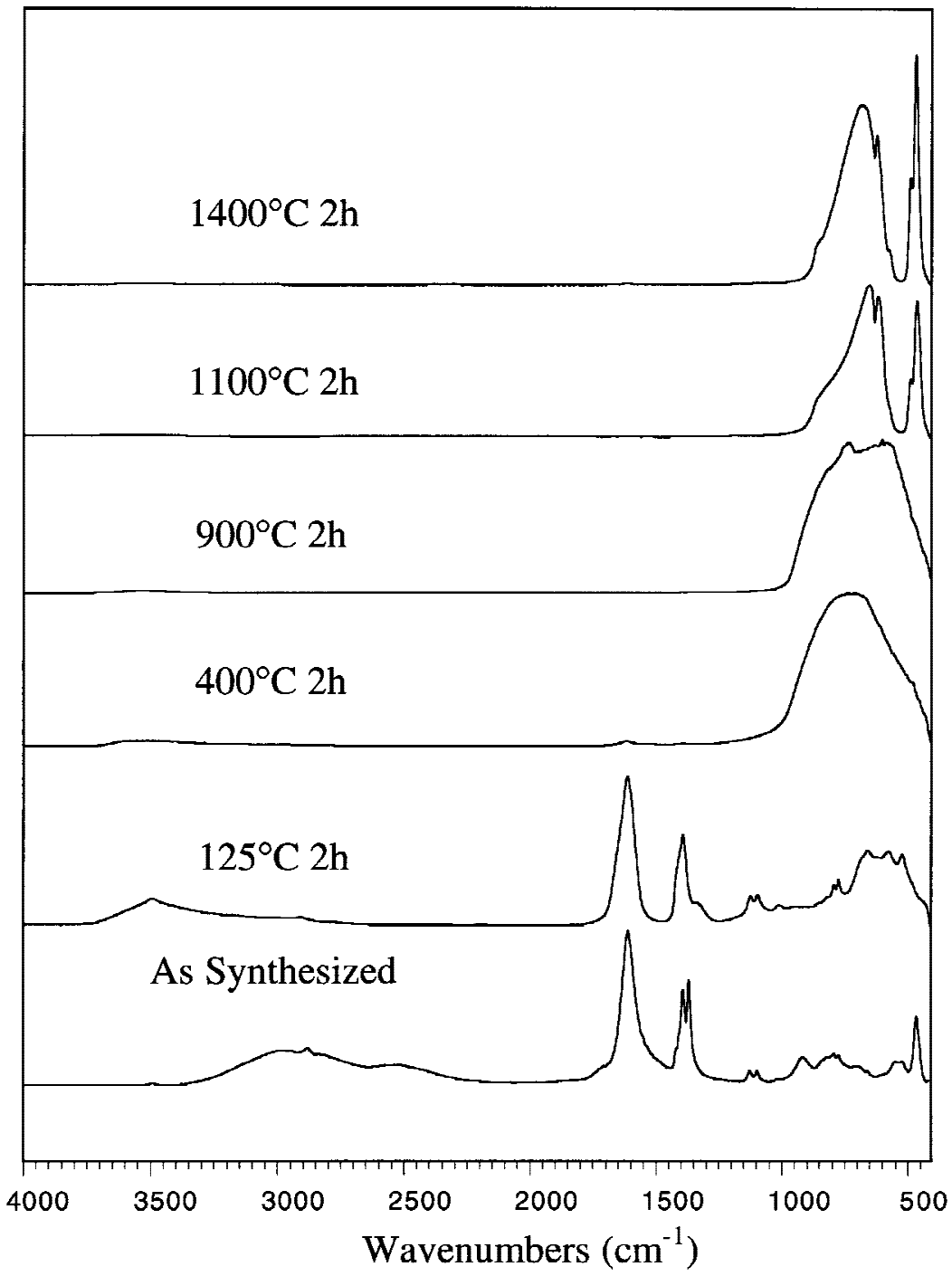

Fig. 3. DRIFTS spectra of $\mathrm{Al}\left(\mathrm{O}_{2} \mathrm{CH}\right)_{3} \cdot 3 \mathrm{H}_{2} \mathrm{O}$ pyrolyzed at selected temperatures. Samples were ramped at $10^{\circ} \mathrm{C} / \mathrm{min}$ in air to the selected temperature, with a holding time of $2 \mathrm{~h}$.

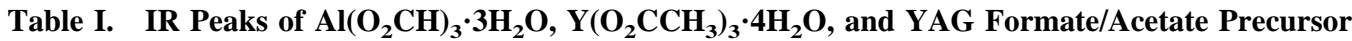

\begin{tabular}{|c|c|c|c|c|c|c|c|}
\hline \multirow[b]{2}{*}{ Compound } & \multicolumn{7}{|c|}{ Wavenumber $\left(\mathrm{cm}^{-1}\right)$} \\
\hline & $v(\mathrm{O}-\mathrm{H})$ & $v(\mathrm{C}-\mathrm{H})$ & $v_{\mathrm{as}}(\mathrm{OCO})$ & $v_{\text {as,def }}(\mathrm{OCO})$ & $v_{\mathrm{s}}(\mathrm{OCO})$ & $v_{\mathrm{s}, \mathrm{def}}(\mathrm{OCO})$ & $v_{\text {def }}(\mathrm{C}-\mathrm{H})$ \\
\hline $\mathrm{Al}\left(\mathrm{O}_{2} \mathrm{CH}\right)_{3} \cdot 3 \mathrm{H}_{2} \mathrm{O}^{\dagger}$ & $3600-2300$ & 2907 & 1620 & 1400 & 1375 & 800 & \\
\hline $\mathrm{AlOH}\left(\mathrm{O}_{2} \mathrm{CH}\right)_{2} \cdot n \mathrm{H}_{2} \mathrm{O}^{\dagger}$ & 3500 & 2930 & 1620 & 1420,1406 & 1385 & 800 & \\
\hline $\mathrm{AlOH}\left(\mathrm{O}_{2} \mathrm{CH}\right)_{2}^{\dagger}$ & 3500 & 2930 & 1630,1605 & 1428,1417 & 1400,1390 & 800,775 & 1080 \\
\hline $\mathrm{Al}\left(\mathrm{O}_{2} \mathrm{CH}\right)_{3} \cdot 3 \mathrm{H}_{2} \mathrm{O}$ & $3600-2300$ & 2900 & 1620 & 1400 & 1380 & 800,780 & \\
\hline $\mathrm{Al}\left(\mathrm{O}_{2} \mathrm{CH}\right)_{3} \cdot 3 \mathrm{H}_{2} \mathrm{O}$ at & & & & & & & \\
\hline $125^{\circ} \mathrm{C}$ & 3500 & 2910 & 1612 & 1391 & 1360 & 793,774 & \\
\hline $\mathrm{Y}\left(\mathrm{O}_{2} \mathrm{CCH}_{3}\right)_{3} \cdot 4 \mathrm{H}_{2} \mathrm{O}$ & $3600-2300$ & $3010,2960,2950$ & 1500 & 1450 & 1340 & & \\
\hline YAG precursor & $3600-2300$ & 2880,2950 & 1600,1720 (tiny) & 1464 & 1380 & & \\
\hline
\end{tabular}

"Data from Chaplygina et $\mathrm{al}^{31}$

tures $>340^{\circ} \mathrm{C}$, TGA indicates a slow mass loss $(\sim 11 \mathrm{wt} \%)$ that corresponds to the evolution of $\mathrm{CO}_{2}$ and some organics (see DRIFTS studies, section $\operatorname{III}(3)(B))$. The ceramic yield $\left(1000^{\circ} \mathrm{C}\right)$ is $33.5 \mathrm{wt} \%$ (Fig. 5), which exactly as calculated for $\mathrm{Y}\left(\mathrm{O}_{2} \mathrm{CCH}_{3}\right)_{3} \cdot 4 \mathrm{H}_{2} \mathrm{O}$, given reactions (6) and (7). The ceramic yield of a sample that has been dried at $80^{\circ} \mathrm{C}$ for $2 \mathrm{~h}$ is $43.0 \mathrm{wt} \%$, as calculated for conversion of $\mathrm{Y}\left(\mathrm{O}_{2} \mathrm{CCH}_{3}\right)_{3}$ to $\mathrm{Y}_{2} \mathrm{O}_{3}$.

The DTA plot (Fig. 6) exhibits endotherms, starting at $50^{\circ} \mathrm{C}$ (centered at $100^{\circ} \mathrm{C}$ ) and $250^{\circ} \mathrm{C}$ (centered at $300^{\circ} \mathrm{C}$ ), and an exotherm at $340^{\circ} \mathrm{C}$ (maximum at $410^{\circ} \mathrm{C}$ ). The $100^{\circ} \mathrm{C}$ endo- therm likely corresponds to the loss of $\mathrm{H}_{2} \mathrm{O}$. The endotherm that is centered at $-300^{\circ} \mathrm{C}$ and the exotherm that is centered at $410^{\circ} \mathrm{C}$ correlate with the major mass loss. Based on the infrared (IR) results below and studies on $\mathrm{Al}\left(\mathrm{O}_{2} \mathrm{CCH}_{3}\right)_{3}$ decomposition, ${ }^{35}$ it is likely that the decomposition process involves ligand loss with some coincidental ligand oxidation, probably per the reactions

$$
\mathrm{Y}\left(\mathrm{O}_{2} \mathrm{CCH}_{3}\right)_{3} \stackrel{\sim 300^{\circ} \mathrm{C}}{\longrightarrow} \mathrm{YO}\left(\mathrm{O}_{2} \mathrm{CCH}_{3}\right)+\left(\mathrm{CH}_{3} \mathrm{CO}\right)_{2} \mathrm{O}
$$

and 


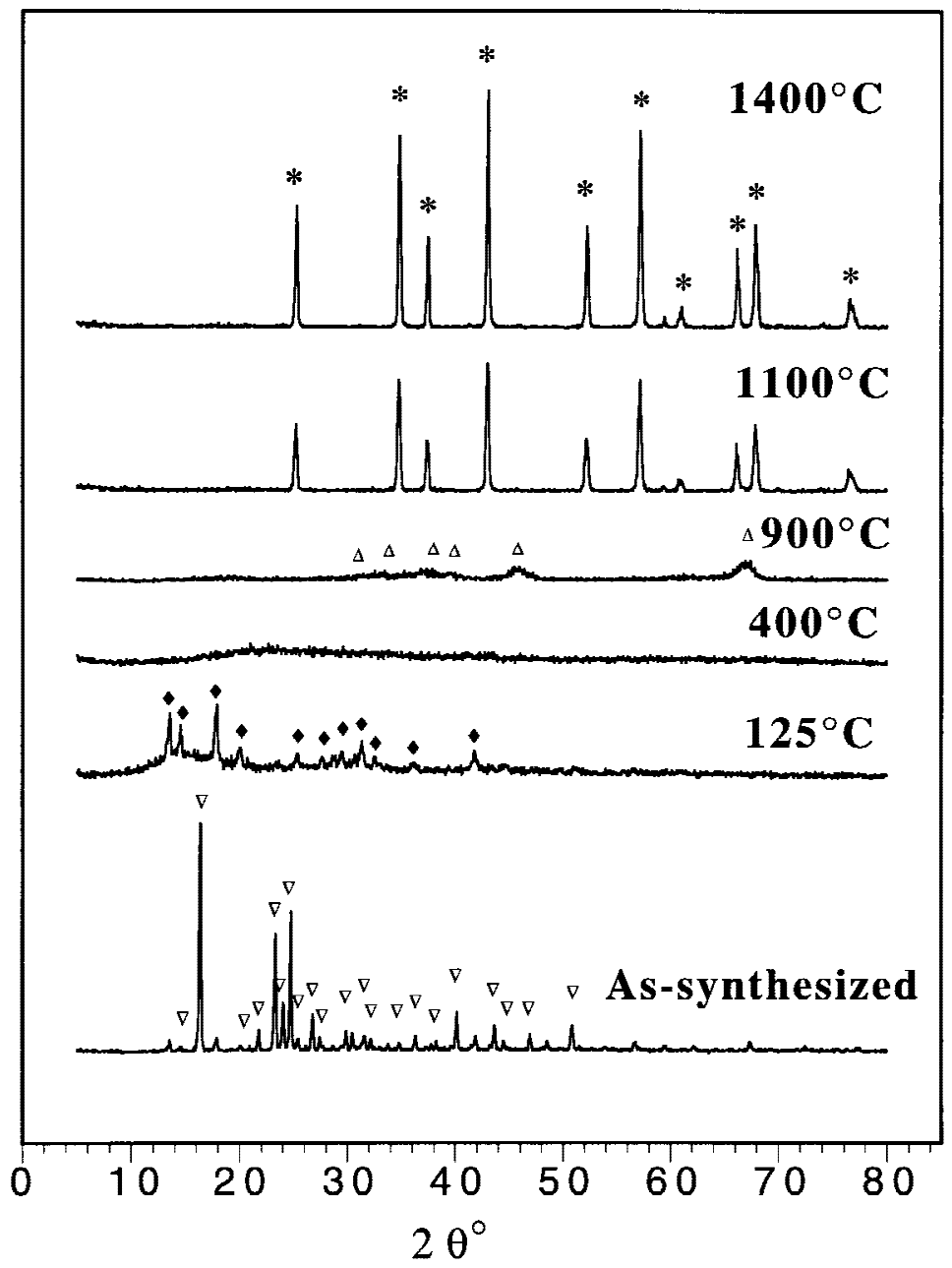

Fig. 4. XRD spectra of $\mathrm{Al}\left(\mathrm{O}_{2} \mathrm{CH}\right)_{3} \cdot 3 \mathrm{H}_{2} \mathrm{O}$ pyrolyzed at selected temperatures; the samples were prepared as in DRIFTS studies $\left((*) \alpha-\mathrm{Al}_{2} \mathrm{O}_{3}\right.$ phase (JCPDS File Card No. 10-173), $(\triangle) \eta-\mathrm{Al}_{2} \mathrm{O}_{3}$ phase (JCPDS File Card No. 4-875), ( $) \mathrm{Al}(\mathrm{OH})\left(\mathrm{O}_{2} \mathrm{CH}\right)_{2} \cdot x \mathrm{H}_{2} \mathrm{O}$ phase (JCPDS File Card No. 37-771), and $(\nabla) \mathrm{Al}\left(\mathrm{O}_{2} \mathrm{CH}\right)_{3} \cdot 3 \mathrm{H}_{2} \mathrm{O}\left(\right.$ Chaplygina et al. $\left.\left.^{31}\right)\right)$.

$$
\begin{aligned}
& \mathrm{YO}\left(\mathrm{O}_{2} \mathrm{CCH}_{3}\right) \stackrel{\sim 400^{\circ} \mathrm{C}}{\longrightarrow} \mathrm{Y}_{2} \mathrm{O}_{3}+\mathrm{Y}_{2}\left(\mathrm{CO}_{3}\right)_{3} \text { (minor) } \\
& + \text { gases }\left(\mathrm{CO}_{2}, \mathrm{H}_{2} \mathrm{O},\left(\mathrm{CH}_{3} \mathrm{CO}\right)_{2} \mathrm{O}, \text { other }\right) \uparrow
\end{aligned}
$$

The ceramic yield for this process would be $\sim 62 \mathrm{wt} \%$, whereas the observed ceramic yield from $265^{\circ}$ to $340^{\circ} \mathrm{C}$ is $\sim 56 \mathrm{wt} \%$. This observation, coupled with the $300^{\circ} \mathrm{C}(2 \mathrm{~h})$ DRIFTS spectrum (below), shows that the continued presence of $v(\mathrm{C}-\mathrm{H})$

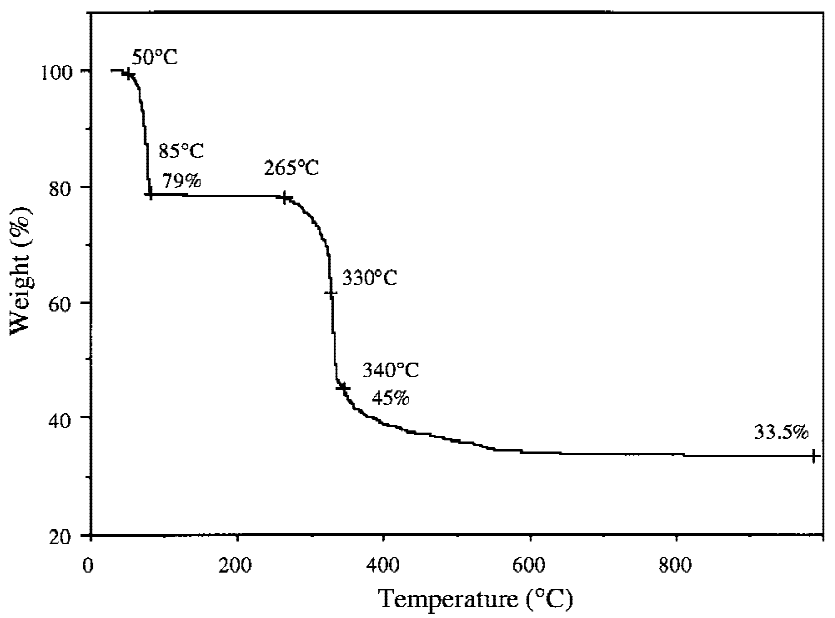

Fig. 5. TGA of $\left.\mathrm{Y}_{2} \mathrm{O}_{2} \mathrm{CCH}_{3}\right)_{3} \cdot 4 \mathrm{H}_{2} \mathrm{O}$ in air. and carboxylate bands, albeit of decreased intensity, provide some support for a reaction akin to reaction (8) that occurs during the decomposition of $\mathrm{Y}\left(\mathrm{O}_{2} \mathrm{CCH}_{3}\right)_{3}$.

Note that experimental differences between the TGA and DTA plots make the temperatures different for the same thermal event, although the TGA and DTA studies were performed

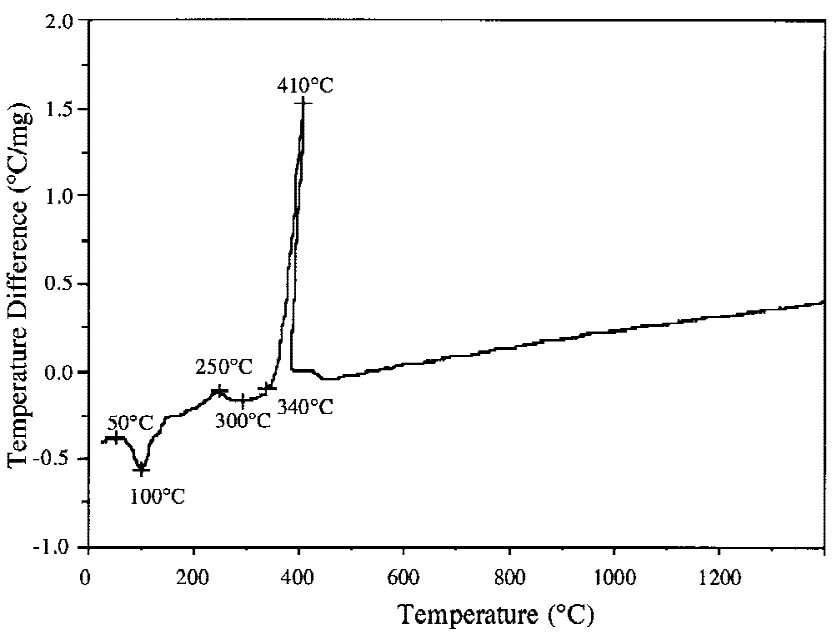

Fig. 6. DTA of $\mathrm{Y}\left(\mathrm{O}_{2} \mathrm{CCH}_{3}\right)_{3} \cdot 4 \mathrm{H}_{2} \mathrm{O}$ in air; the sample was heated at the same heating rate as TGA for $\mathrm{Y}\left(\mathrm{O}_{2} \mathrm{CCH}_{3}\right)_{3} \cdot 4 \mathrm{H}_{2} \mathrm{O}$ at temperatures $<1000^{\circ} \mathrm{C}$ and then at $10^{\circ} \mathrm{C} / \mathrm{min}$ to $1500^{\circ} \mathrm{C}$ at temperatures $>1000^{\circ} \mathrm{C}$. 
at the same heating rate. In the DTA, the air flows (from below) past the sample pan; therefore, no fresh air flows directly on the sample, as in the TGA. Also, the DTA sample pan is deeper than the TGA pan and seems to form a dead-air zone; therefore, less sample surface is exposed to fresh air. Thus, the dead zone in the DTA inhibits decomposition, and these reactions have a tendency to start at higher temperatures. In our previous study on the pyrolysis behavior of $\mathrm{Y}\left(\mathrm{O}_{2} \mathrm{CCHMe}_{2}\right)_{3}$, bcc $\mathrm{Y}_{2} \mathrm{O}_{3}$ crystallized at $300^{\circ} \mathrm{C} / 2 \mathrm{~h}$. An exotherm that was associated with crystallization was observed beginning at $280^{\circ} \mathrm{C}$ (maximized at $380^{\circ} \mathrm{C} .^{1}$

(B) DRIFTS: Figure 7 displays DRIFTS spectra for $\mathrm{Y}\left(\mathrm{O}_{2} \mathrm{CCH}_{3}\right)_{3} \cdot 4 \mathrm{H}_{2} \mathrm{O}$ samples that have been pyrolyzed using the same procedures as those which were used for $\mathrm{Al}\left(\mathrm{O}_{2} \mathrm{CH}\right)_{3}$. $3 \mathrm{H}_{2} \mathrm{O}$. The spectrum of $\mathrm{Y}\left(\mathrm{O}_{2} \mathrm{CCH}_{3}\right)_{3} \cdot 4 \mathrm{H}_{2} \mathrm{O}$ (lowest inset in Fig. 7) shows weak $v(\mathrm{O}-\mathrm{H})$ bands in the wave number range of $3500-2800 \mathrm{~cm}^{-1}$, weak $v(\mathrm{C}-\mathrm{H})$ bands at 3010, 2960, and 2950 $\mathrm{cm}^{-1}$, and strong $v(\mathrm{C}=\mathrm{O})$ bands at 1560, 1450, and 1350 $\mathrm{cm}^{-1} \cdot 34$

As shown in the insets, when heated to $120^{\circ}$ and then $300^{\circ} \mathrm{C}$, the $v(\mathrm{C}-\mathrm{H})$ band intensities diminish as $\mathrm{Y}\left(\mathrm{O}_{2} \mathrm{CCH}_{3}\right)_{3} \cdot 4 \mathrm{H}_{2} \mathrm{O}$ seems to decompose to $\mathrm{YO}\left(\mathrm{O}_{2} \mathrm{CCH}_{3}\right)$ or some related product. The continued presence of $v(\mathrm{O}-\mathrm{H})$ bands may indicate a different product or the fact that the samples are prepared in air and DRIFTS emphasizes surface species (e.g., water that has been physisorbed during sample preparation). Most peaks at wave numbers $<1750 \mathrm{~cm}^{-1}$ remain unchanged, as also observed by Hussein. ${ }^{34}$ However, a weak $v(\mathrm{Y}-\mathrm{O})$ band at $560 \mathrm{~cm}^{-1}$ suggests the presence of $\mathrm{Y}_{2} \mathrm{O}_{3} \cdot{ }^{1,36}$ The $560 \mathrm{~cm}^{-1}$ peak grows in intensity at higher temperatures. In the $\mathrm{Y}\left(\mathrm{O}_{2} \mathrm{CCHMe}_{2}\right)_{3}$ pyrolysis studies, where bcc $\mathrm{Y}_{2} \mathrm{O}_{3}$ forms at $300^{\circ} \mathrm{C} / 2 \mathrm{~h}$, DRIFTS peaks that correspond to crystalline $\mathrm{Y}_{2} \mathrm{O}_{3}$

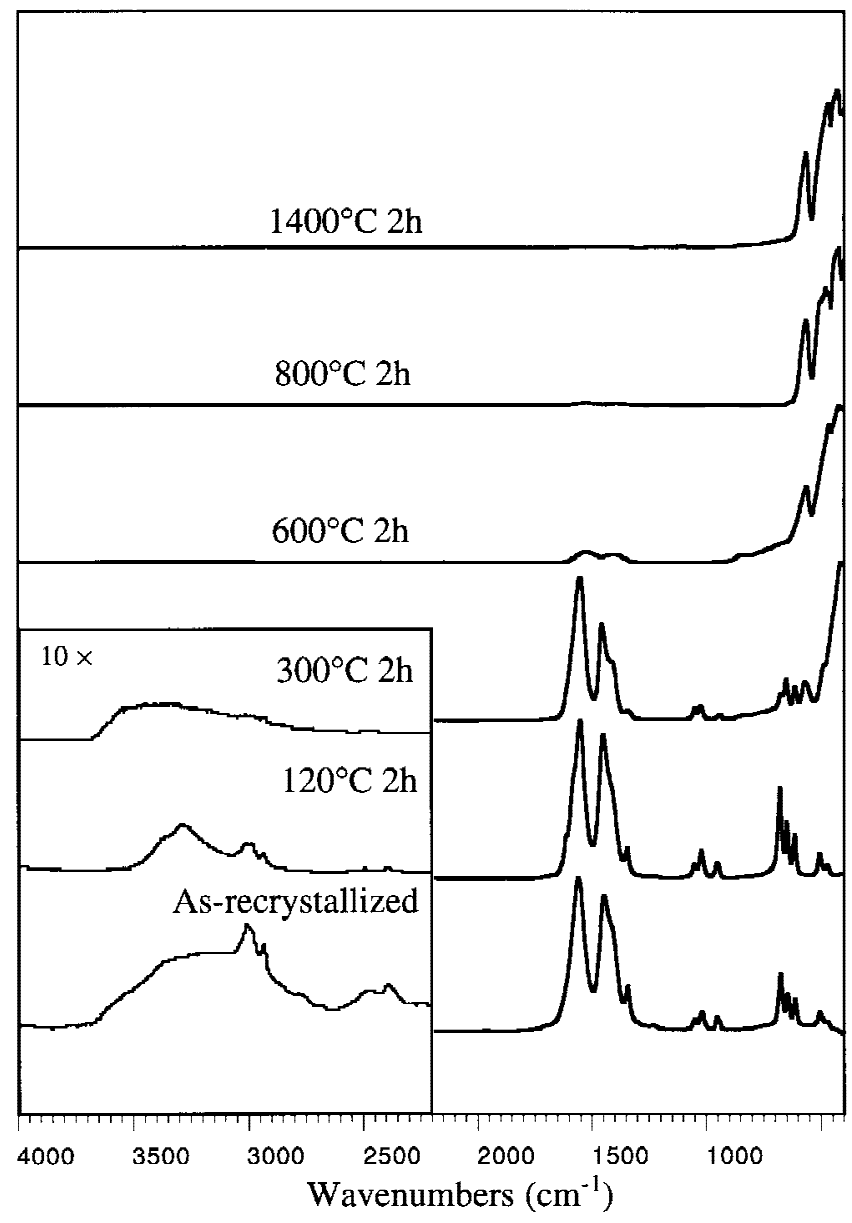

Fig. 7. DRIFTS spectra of $\mathrm{Y}_{2}\left(\mathrm{O}_{2} \mathrm{CCH}_{3}\right)_{3} \cdot 4 \mathrm{H}_{2} \mathrm{O}$ pyrolyzed at $10^{\circ} \mathrm{C} /$ min $(2 \mathrm{~h} \mathrm{dwell})$ in air at the selected temperatures. appeared simultaneously at 560,470 , and $430 \mathrm{~cm}^{-1} \cdot{ }^{1,34}$ In the current study, the $300^{\circ} \mathrm{C} / 2 \mathrm{~h}$ pyrolyzed $\mathrm{Y}\left(\mathrm{O}_{2} \mathrm{CCH}_{3}\right)_{3} \cdot 4 \mathrm{H}_{2} \mathrm{O}$ sample likely consists of a mixture of $\mathrm{Y}_{2} \mathrm{O}_{3}$ and $\mathrm{YO}\left(\mathrm{O}_{2} \mathrm{CCH}_{3}\right)$. It is also possible that some carbonate forms; however, the carbonate bands would be hidden beneath the $v(\mathrm{C}=\mathrm{O})$ bands.

At $500^{\circ} \mathrm{C}$ (DRIFTS spectrum not shown), the $v(\mathrm{C}=\mathrm{O}$ ) bands disappear, and carbonate peaks appear at 1530 and 1405 $\mathrm{cm}^{-1}$, which suggests the formation of $\mathrm{Y}_{2}\left(\mathrm{CO}_{3}\right)_{3}$. The $600^{\circ} \mathrm{C}$ spectrum is quite similar to the $500^{\circ} \mathrm{C}$ spectrum, except for a decrease in the carbonate peak intensities. These peaks finally disappear at $800^{\circ} \mathrm{C}$, which indicates the complete elimination of carbonate. Indeed, most of the carbonate is gone by $600^{\circ} \mathrm{C}$; only an additional $2 \mathrm{wt} \%$ loss is observed. The remaining material is assumed to be stoichiometric $\mathrm{Y}_{2} \mathrm{O}_{3}$. The intensities of the peaks at 560,470 , and $430 \mathrm{~cm}^{-1}$ increase as the temperature increases from $500^{\circ} \mathrm{C}$ to $1400^{\circ} \mathrm{C}$, which indicates continued crystallization and/or grain growth of $\mathrm{Y}_{2} \mathrm{O}_{3}$, as supported by XRD studies. Again, all the intermediate pyrolysis samples were white powders.

(C) Powder X-ray Diffractometry (XRD) Patterns: Figure

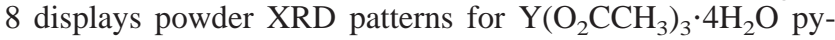
rolysis samples that were produced as in the DRIFTS studies. The XRD pattern for the as-recrystallized sample is similar to that of Hussein. ${ }^{34}$ Although there is no significant change in the DRIFTS spectrum for the sample pyrolyzed to $300^{\circ} \mathrm{C}$, the XRD data for the recrystallized samples pyrolyzed to $120^{\circ}$ and $300^{\circ} \mathrm{C}$ are quite different, which suggests structural changes when heated. Although Hussein ${ }^{34}$ suggested that crystalline

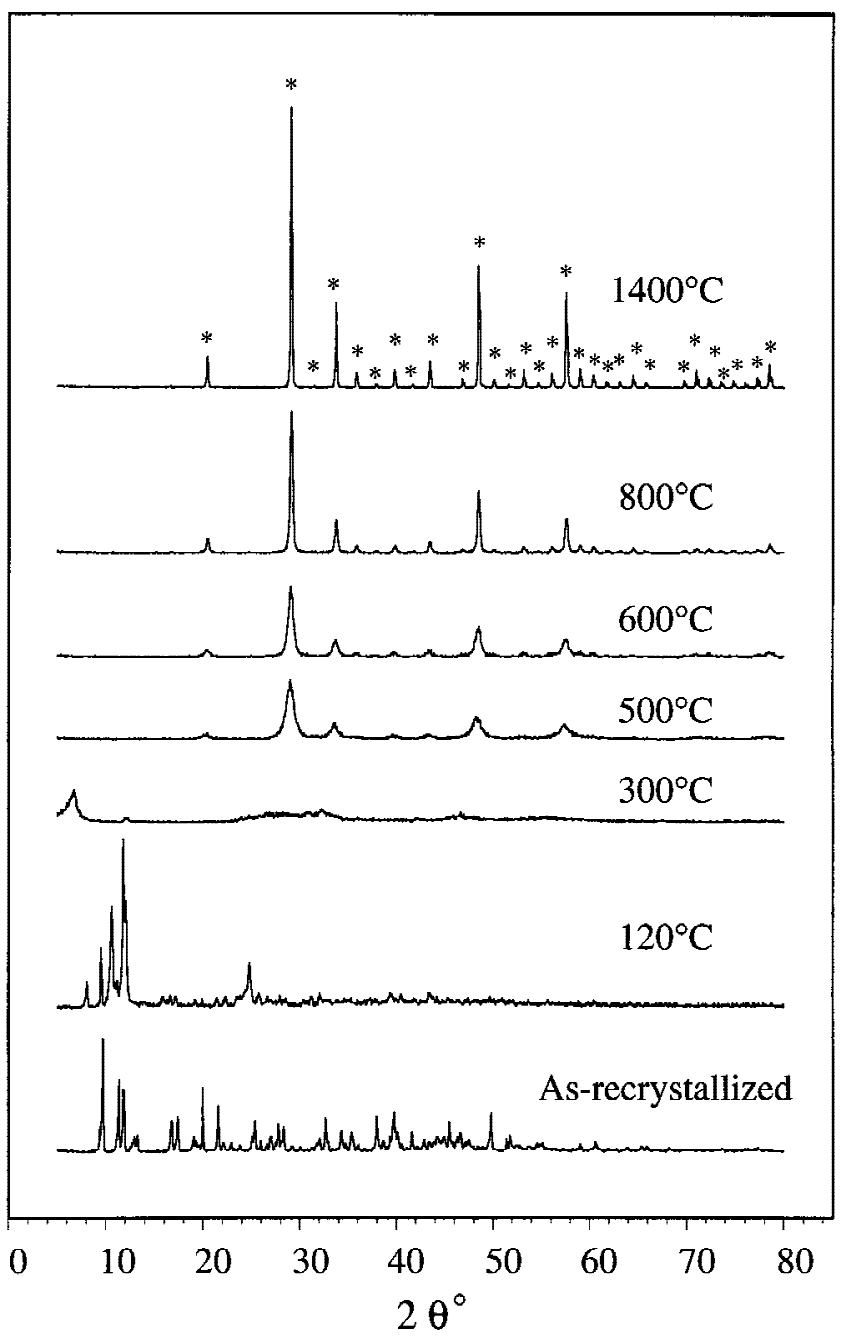

Fig. 8. XRD spectra of $\mathrm{Y}\left(\mathrm{O}_{2} \mathrm{CCH}_{3}\right)_{3} \cdot 4 \mathrm{H}_{2} \mathrm{O}$ pyrolyzed at selected temperatures; the samples were prepared as in DRIFTS studies $\left(\left(^{*}\right)\right.$ bcc yttria (JCPDS File Card No. 41-1105)). 
$\mathrm{Y}\left(\mathrm{O}_{2} \mathrm{CCH}_{3}\right)_{3}$ is stable to $350^{\circ} \mathrm{C} / 1 \mathrm{~h}$, our XRD data indicate the formation of a new, intermediate crystalline or partially crystalline phase at $300^{\circ} \mathrm{C} / 2 \mathrm{~h}$. This phase may correspond to "' $\mathrm{YO}\left(\mathrm{O}_{2} \mathrm{CCH}_{3}\right)$,', which is suggested by the TGA, DTA, and DRIFTS evidence and the work on the aluminum analogue. ${ }^{35}$ However, no further evidence is available to support this explanation.

At $500^{\circ} \mathrm{C}$, the $\mathrm{XRD}$ pattern shows crystalline bcc $\mathrm{Y}_{2} \mathrm{O}_{3}$; however, the broad peaks and low intensities suggest that considerable material is either amorphous or nanocrystalline, as observed in the $\mathrm{XRD}$ profile for $\mathrm{Y}\left(\mathrm{O}_{2} \mathrm{CiPr}\right)_{3}$ at $300^{\circ} \mathrm{C} .{ }^{1} \mathrm{It}$ is possible that the presence of carbonate inhibits crystallization; however, no evidence supports this conjecture. At higher temperatures $\left(\geq 600^{\circ} \mathrm{C}\right)$, the XRD intensities increase and the peak widths narrow, which indicates better crystallization. At $1400^{\circ} \mathrm{C}$, the $\mathrm{XRD}$ profile indicates well-crystallized $\mathrm{Y}_{2} \mathrm{O}_{3}$.

\section{(4) Characterization of $3 \mathrm{Y}\left(\mathrm{O}_{2} \mathrm{CCH}_{3}\right)_{3}: 5 \mathrm{Al}\left(\mathrm{O}_{2} \mathrm{CH}\right)_{3} \mathrm{YAG}$ Precursor Mixture}

The YAG precursor was prepared by dissolution of the correct stoichiometric mixture in $\mathrm{H}_{2} \mathrm{O}$, formic acid, isobutyric acid, and ethylene glycol, followed by vacuum evaporation of the solvent and grinding of the resulting powder, as detailed in the experimental section. Samples of this bulk powder were then pyrolyzed to selected temperatures as discussed previously.

(A) Thermal Analysis: The TGA plot of the bulk, dry $\left(100^{\circ} \mathrm{C} / 2 \mathrm{~h}\right)$ powder (Fig. 9) seems to show a decomposition profile that is not a simple superposition of both $\mathrm{Al}\left(\mathrm{O}_{2} \mathrm{CH}\right)_{3}$. $3 \mathrm{H}_{2} \mathrm{O}$ and $\mathrm{Y}\left(\mathrm{O}_{2} \mathrm{CCH}_{3}\right)_{3} \cdot 4 \mathrm{H}_{2} \mathrm{O}$ decomposition profiles. There are five mass-loss steps during decomposition, according to the derivative curve. The first one, beginning at $120^{\circ} \mathrm{C}$ (mass loss of $10 \mathrm{wt} \%$ ), corresponds to the elimination of water and loosely bound organics. The second one, from $180^{\circ} \mathrm{C}$ (centered at $210^{\circ} \mathrm{C}$, mass loss of $8 \mathrm{wt} \%$ ), corresponds to the partial decomposition of carboxylate ligands, possibly via reactions (3) and (8). The third mass loss, from $240^{\circ} \mathrm{C}$ (centered at $310^{\circ} \mathrm{C}$, mass loss of $30 \mathrm{wt} \%$ ), probably corresponds to the decomposition of the residual carboxylate ligands, as $v(\mathrm{C}-\mathrm{H})$ bands disappear (see DRIFTS section) and the color of the sample changes from white to light brown. The fourth loss, from $400^{\circ} \mathrm{C}$ to $920^{\circ} \mathrm{C}$ (mass loss of $9 \mathrm{wt} \%$ ), is associated with carbonate decomposition. The sample coincidently becomes black at temperatures $>600^{\circ} \mathrm{C}$. The fifth loss, from $930^{\circ}$ to $1000^{\circ} \mathrm{C}$ (mass loss of 3 $\mathrm{wt} \%$ ), results from the oxidation of trace amounts of free carbon, as samples change from black to white. The presence of residual carbon at such high temperatures, in an oxidizing atmosphere, is not commonly observed for the pyrolytic decomposition of aluminosilicates, nor was such behavior noted in the isobutyrate studies. ${ }^{14}$

The found ceramic yield is $40.0 \mathrm{wt} \%$, whereas a ceramic yield of $28.3 \mathrm{wt} \%$ is calculated for $\left.3\left[\mathrm{Y}_{(2} \mathrm{O}_{2} \mathrm{CCH}_{3}\right)_{3} \cdot 4 \mathrm{H}_{2} \mathrm{O}\right]$. $5\left[\mathrm{Al}\left(\mathrm{O}_{2} \mathrm{CH}\right)_{3} \cdot 3 \mathrm{H}_{2} \mathrm{O}\right]$. The calculated ceramic yield for anhydrous $3\left[\mathrm{Y}_{(}\left(\mathrm{O}_{2} \mathrm{CCH}_{3}\right)_{3}\right] \cdot 5\left[\mathrm{Al}\left(\mathrm{O}_{2} \mathrm{CH}\right)_{3}\right]$ is $36.9 \mathrm{wt} \%$, which is also lower than the found value. It is possible that some $\mathrm{Al}\left(\mathrm{O}_{2} \mathrm{CH}\right)_{3} \cdot 3 \mathrm{H}_{2} \mathrm{O}$ transforms to $\mathrm{Al}(\mathrm{OH})\left(\mathrm{O}_{2} \mathrm{CH}\right)_{2}$ when the YAG precursor is vacuum dried at $100^{\circ} \mathrm{C}$. The calculated ceramic yield for $3\left[\mathrm{Y}_{2}\left(\mathrm{O}_{2} \mathrm{CCH}_{3}\right)_{3}\right] \cdot 5\left[\mathrm{Al}(\mathrm{OH})\left(\mathrm{O}_{2} \mathrm{CH}\right)_{2}\right]$ is 40.4 wt $\%$, which is similar to the TGA ceramic yield. However, the DRIFTS data do not show the presence of $\nu(\mathrm{O}-\mathrm{H})$. Alternately, the precursor is actually $3\left[\mathrm{Y}\left(\mathrm{O}_{2} \mathrm{CH}\right)_{3}\right] \cdot 5\left[\mathrm{Al}\left(\mathrm{O}_{2} \mathrm{CH}\right)_{3}\right]$, which offers a ceramic yield of $40.1 \mathrm{wt} \%$, which also is similar to that found. The acetate ligands may exchange with the free $\mathrm{HCO}_{2} \mathrm{H}$ that has been used as a stabilizer during precursor synthesis.

In Fig. 10, the DTA shows three exotherms at temperatures $<900^{\circ} \mathrm{C}$. The first one, which is centered at $230^{\circ} \mathrm{C}$, likely corresponds to the second mass loss step in the TGA and may be associated with the partial decomposition of formate to $\mathrm{M}(\mathrm{OH})\left(\mathrm{O}_{2} \mathrm{CH}\right)_{2}(\mathrm{M}=\mathrm{Al}$ and/or $\mathrm{Y}$ ) species (see DRIFTS, section $\operatorname{III}(4)(B))$. The second exotherm, which is centered at $340^{\circ} \mathrm{C}$ (third mass loss step in TGA, $260^{\circ}-420^{\circ} \mathrm{C}$ ), corresponds to a mass loss of $\sim 30 \mathrm{wt} \%$ in TGA. In this temperature range, the carboxylate ligands decompose primarily to carbonate and oxide species (see DRIFTS, section $\operatorname{III}(4)(B)$ ). The third exotherm, which is centered at $440^{\circ} \mathrm{C}$ (fourth step in the TGA, mass loss of $\sim 3 \mathrm{wt} \%$ ), likely corresponds to the oxidation of residual organics and network formation. ${ }^{14}$ However, the black color of the materials clearly indicates the presence of some residual carbon.

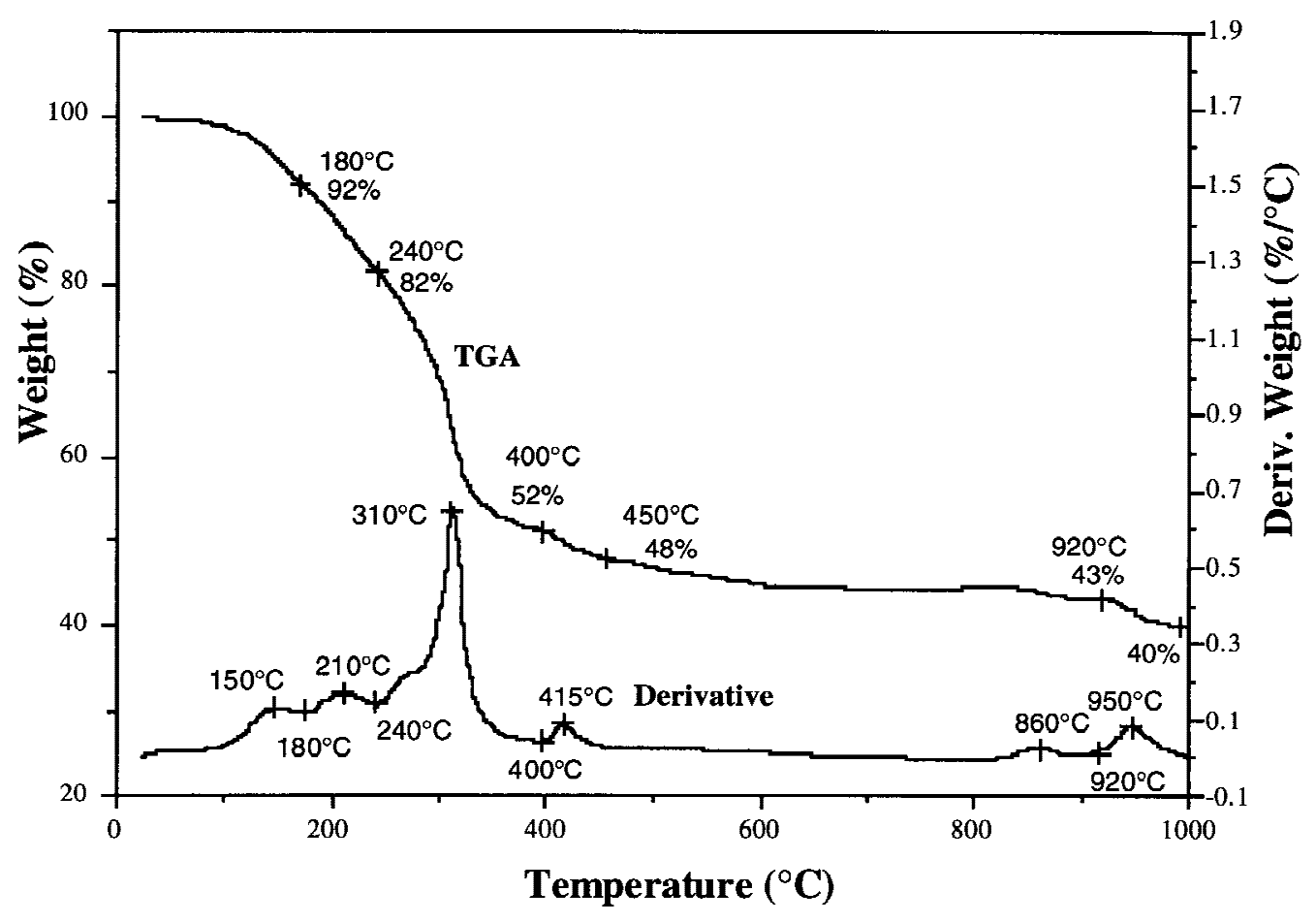

Fig. 9. TGA of YAG formate/acetate precursor in air. 


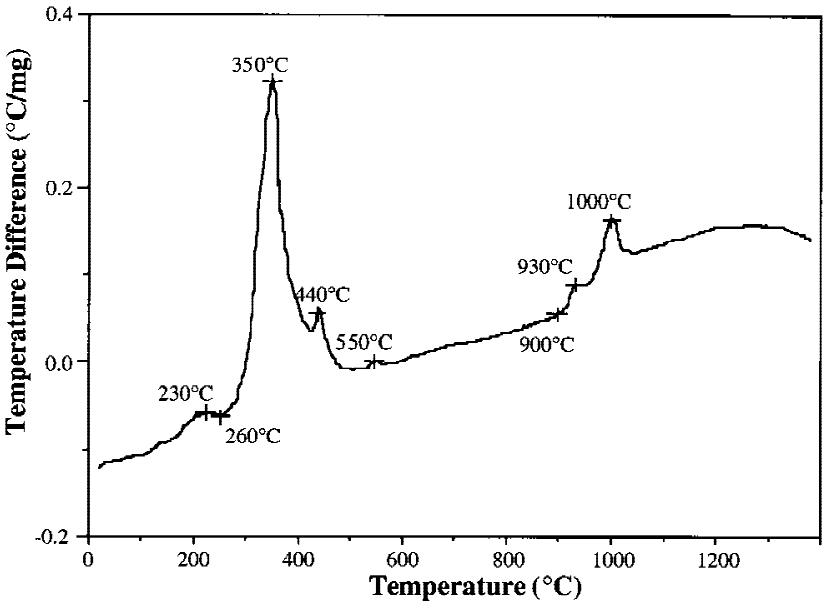

Fig. 10. DTA of YAG formate/acetate precursor in air.

None of the DTA peaks has a common position with the DTA studies of the individual aluminum and yttrium compounds (Figs. 2 and 6). Such behavior implies that the YAG precursor is not simply a mechanical mixture of the individual aluminum and yttrium compounds. For example, the YAG precursor that has been pyrolyzed at $600^{\circ}-800^{\circ} \mathrm{C} / 2 \mathrm{~h}$ is black, although neither the aluminum nor the yttrium carboxylates generate black pyrolysis products. We have previously observed similar synergistic behavior following THF dissolution and recovery of mixtures of $\mathrm{Cu} / \mathrm{Ba}$ and Y/Al isobutyrates. ${ }^{1,7}$

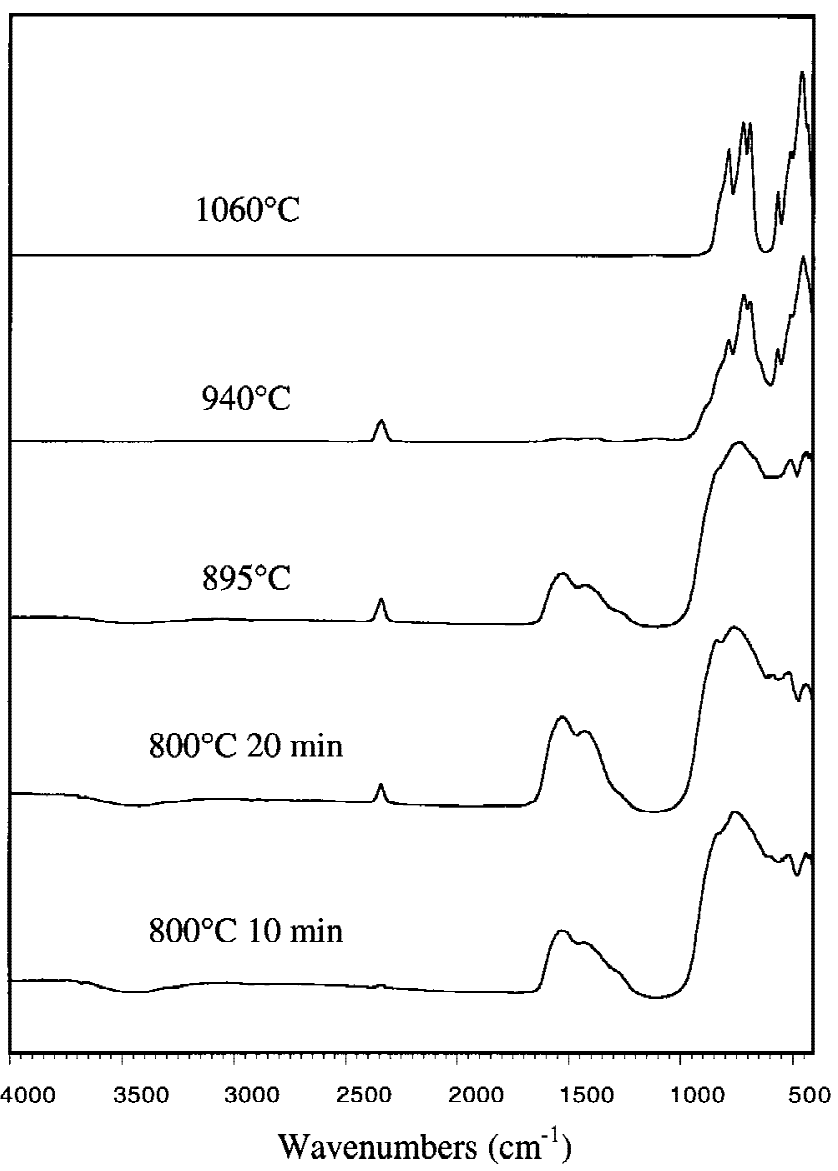

Fig. 11. DRIFTS spectra of DTA-pyrolyzed YAG formate/acetate precursor; the samples were heated at $10^{\circ} \mathrm{C} / \mathrm{min}$ to the selected temperature, with a holding time of $\sim 1 \mathrm{~s}$ for $895^{\circ}, 940^{\circ}$, and $1060^{\circ} \mathrm{C}$.
One possible interpretation is that a mixed-metal carboxylate complex is forming; however, we have not sought to explore this possibility.

The DTA (Fig. 10) also shows two exotherms, at $930^{\circ}$ and $1000^{\circ} \mathrm{C}$ (fifth step in the TGA). Because we were concerned about the origin of both peaks, an additional DRIFTS study was conducted with the DTA samples. A series of DRIFTS spectra were taken between the two exotherms, to follow the evolution of the precursor (Fig. 11). The YAG precursor powder remained black until just above $890^{\circ} \mathrm{C}$, which is the temperature below the onset point of the first exotherm. At $895^{\circ} \mathrm{C}$ (no dwell time), the sample displayed broad carbonate peaks with reasonably strong intensities, as does the $400^{\circ} \mathrm{C} / 2 \mathrm{~h}$ amorphous sample in Fig. 12 . Between $930^{\circ}$ and $1000^{\circ} \mathrm{C}$, the sample was gray. The DRIFTS analysis for a sample that has been heated at $940^{\circ} \mathrm{C}$ (no dwell time) shows a typical crystalline YAG profile, with the carbonate peaks absent (Fig. 11). At $1060^{\circ} \mathrm{C}$, where the second exotherm is complete, the sample was white. The DRIFTS analysis for the sample that has been held at $1060^{\circ} \mathrm{C}$ (no dwell time) is almost the same as the DRIFTS analysis for the $940^{\circ} \mathrm{C}$ sample, which suggests no changes at the atomic level. Based on the above-mentioned observations, one can conclude that the first exotherm results from the oxidation of carbon and the second results from the crystallization of YAG.

(B) DRIFTS: Figure 12 displays spectra of the asprocessed YAG precursor and samples that have been heated to selected temperatures. The as-processed $\mathrm{YAG}$ precursor spectrum (bottom) is similar to that of $\mathrm{Al}\left(\mathrm{O}_{2} \mathrm{CH}\right)_{3} \cdot 3 \mathrm{H}_{2} \mathrm{O}$ but with broader peaks. It is possible that the $\mathrm{Y}\left(\mathrm{O}_{2} \mathrm{CCH}_{3}\right)_{3} \cdot 4 \mathrm{H}_{2} \mathrm{O}$ peaks are hidden by $\mathrm{Al}\left(\mathrm{O}_{2} \mathrm{CH}\right)_{3} \cdot 3 \mathrm{H}_{2} \mathrm{O}$ peaks, because of the higher concentration of the aluminum compound, or a new mixedmetal complex forms. Alternately, based on the changes in ceramic yield, the acetate ligands may have been displaced by formate ligands during synthesis of the YAG precursor.

At $250^{\circ} \mathrm{C}$, the major peak positions do not change; however,

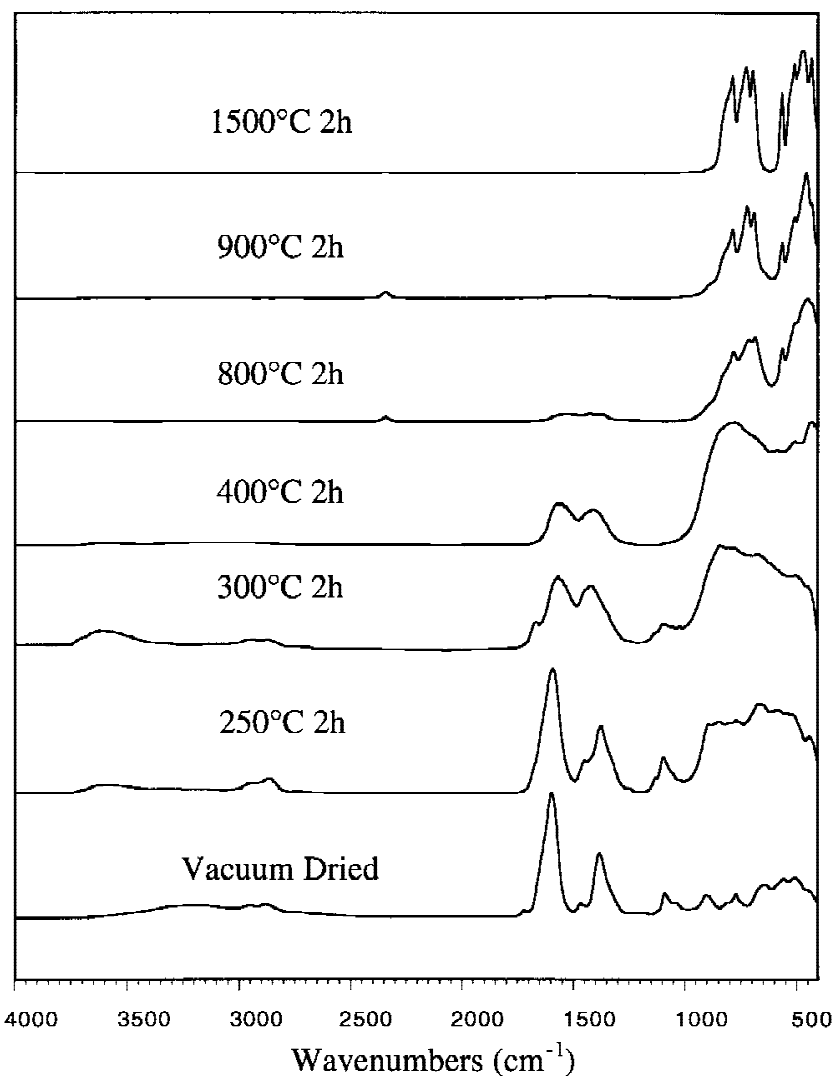

Fig. 12. DRIFTS spectra of YAG formate/acetate precursor heated at $10^{\circ} \mathrm{C} / \mathrm{min}$ to selected temperatures, followed by a holding time of $2 \mathrm{~h}$. 


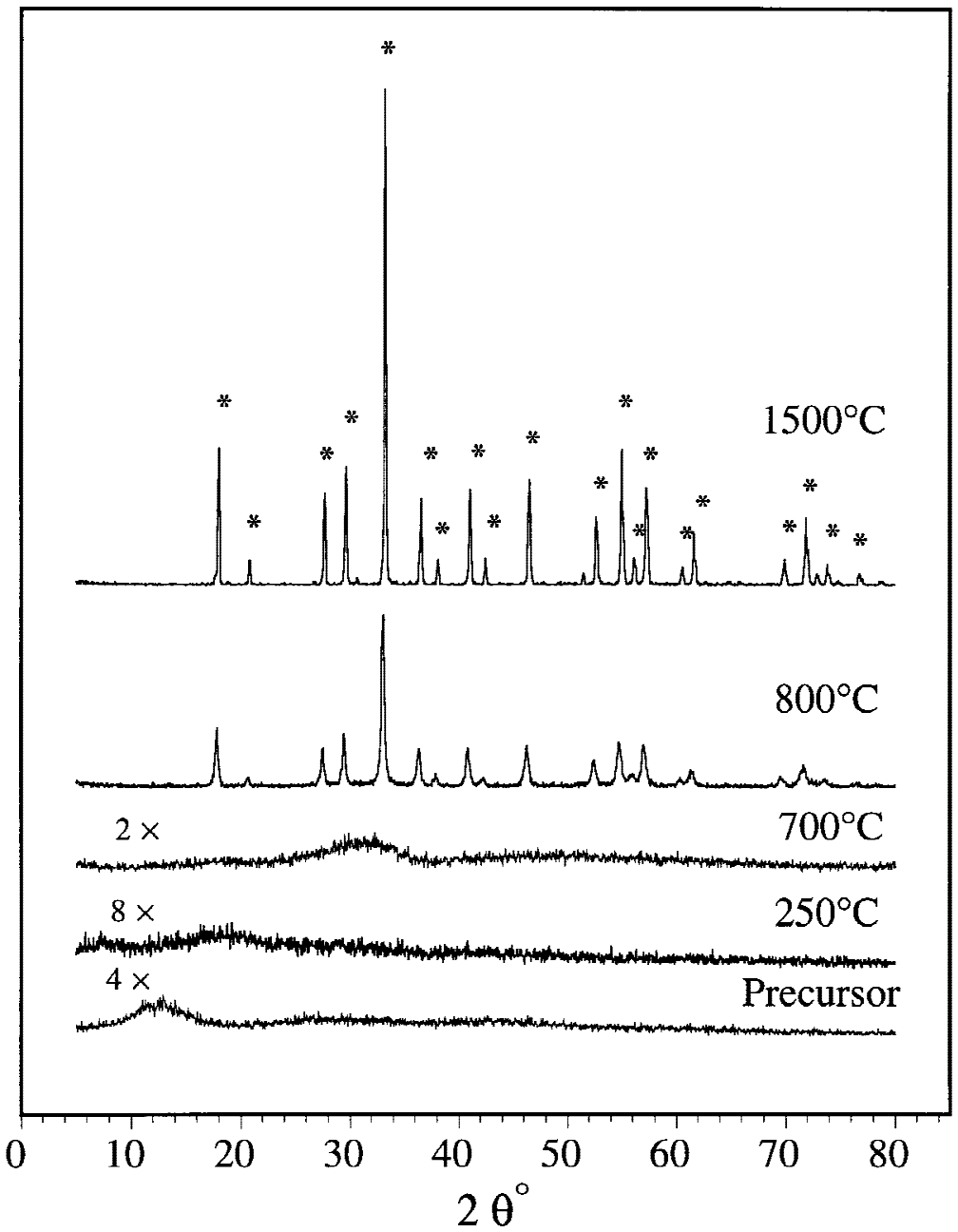

Fig. 13. XRD spectra of YAG formate/acetate precursor pyrolyzed to selected temperatures; the samples were treated as in DRIFTS studies ((*) YAG (JCPDS File Card No. 33-40)).

the broad $v(\mathrm{OH})$ band at $3600-3200 \mathrm{~cm}^{-1}$ (hydrate water) disappears and a $v(\mathrm{OH})$ band appears at $3700-3400 \mathrm{~cm}^{-1}$ that can be assigned to $\mathrm{O}-\mathrm{H}$ stretches of $\mathrm{Al} / \mathrm{Y}$ hydroxyl groups, which suggests partial hydrolytic decomposition (e.g., reaction (3)).

At $300^{\circ} \mathrm{C}$, the $v(\mathrm{C}=\mathrm{O})$ bands at 1600,1464 , and $1380 \mathrm{~cm}^{-1}$ disappear and carbonate peaks that are centered at 1530 and $1400 \mathrm{~cm}^{-1}$ appear. The $\nu(\mathrm{C}-\mathrm{H})$ bands at 2950 and $2880 \mathrm{~cm}^{-1}$, and the $v(\mathrm{O}-\mathrm{H})$ band at $3700-3400 \mathrm{~cm}^{-1}$ are still observed in the spectrum, which suggests that carboxylate ligand decomposition is incomplete.

At $400^{\circ} \mathrm{C}$, all bands that are associated with the carboxylate ligands disappear (in the YAG isobutyrate precursor study, the carboxylate ligands disappear at $300^{\circ} \mathrm{C}$ ). ${ }^{1}$ Two broad carbonate peaks centered at 1530 and $1400 \mathrm{~cm}^{-1}$ appear. All the remaining peaks are broad as well, which indicates an amorphous material.

The carbonate peaks persist to only $800^{\circ} \mathrm{C}$ (note $2 \mathrm{~h}$ dwell versus no dwell in Fig. 11), as observed for the isobutyrate precursor. ${ }^{1}$ The broad peaks at $650-1000 \mathrm{~cm}^{-1}$ in the $300^{\circ}$ $400^{\circ} \mathrm{C}$ spectra evolve into a set of peaks at temperatures $\geq 800^{\circ} \mathrm{C}$ that correspond to the crystallization of YAG. ${ }^{1,37}$

(C) XRD: Figure 13 provides XRD powder patterns of bulk YAG precursor samples that have been pyrolyzed to selected temperatures. As with the YAG isobutyrate studies, ${ }^{1}$ no intermediate crystalline phases (e.g., bcc $\mathrm{Y}_{2} \mathrm{O}_{3}, \eta$ - or $\alpha-\mathrm{Al}_{2} \mathrm{O}_{3}$ ) are observed before the crystallization of YAG $\left(\sim 800^{\circ} \mathrm{C}\right)$. Formate/acetate-derived YAG crystallizes at temperatures that are $\sim 100^{\circ} \mathrm{C}$ lower than the isobutyrate precursor. ${ }^{1}$

The dried precursor exhibits broad peaks centered at $12^{\circ} 2 \theta$, which is typical of an amorphous material. When the precursor is heated to $700^{\circ} \mathrm{C}$, this peak shifts to $30^{\circ} 2 \theta$, which indicates a change in the amorphous structure, perhaps suggesting some local ordering, as implied by the peaks at $650-1000 \mathrm{~cm}^{-1}$ in the DRIFTS spectra at the same temperature. This type of behavior

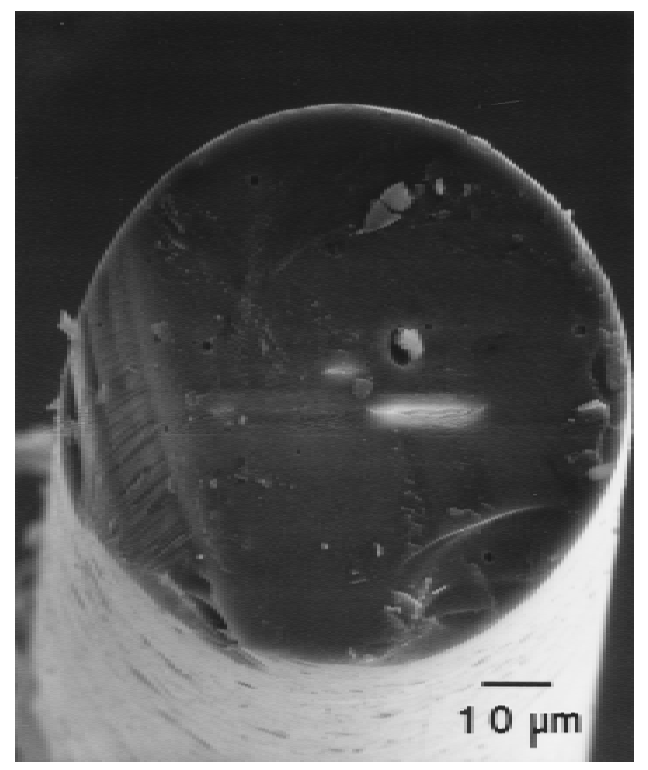

Fig. 14. SEM micrograph of as-spun extruded YAG isobutyrate precursor fiber. 


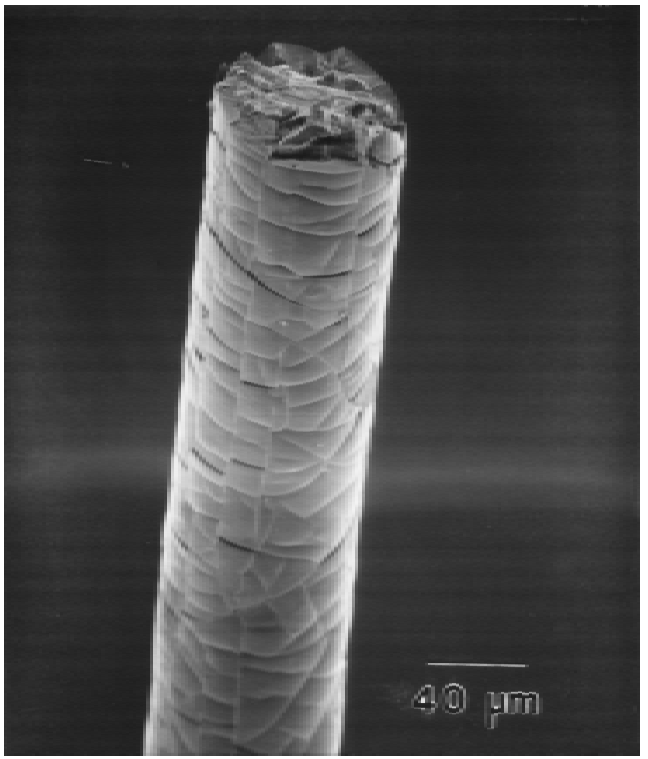

Fig. 15. SEM micrograph of extruded isobutyrate precursor fiber cured at $1^{\circ} \mathrm{C} / \mathrm{min}$ to $160^{\circ} \mathrm{C}$ (dwell time of $2 \mathrm{~h}$ ).

has been termed "noncrystalline but not completely amorphous.' 1,13

The appearance of crystalline YAG at temperatures that are $\sim 100^{\circ} \mathrm{C}$ lower than YAG from the isobutyrate precursor may suggest better atomic mixing, a lower stability precursor, or better nucleation of crystallites during decomposition, because of a higher impurity level. The exact reasons for this behavior cannot be explained at present.

At temperatures $>800^{\circ} \mathrm{C}$, YAG continues to crystallize, as evidenced by the continued refinement in peak shapes and intensities. The difference in phase-transformation temperatures between the DTA and IR/XRD analyses is due to differences in the heating schedule, because crystallization of YAG at $800^{\circ} \mathrm{C}$ is not only temperature dependent, but also is atmosphere and time dependent. The IR/XRD samples were heat treated at selected temperatures for $2 \mathrm{~h}$, whereas the DTA data were obtained for samples that were heated continuously to $1500^{\circ} \mathrm{C}$. A longer heating time, at lower temperatures, gener-

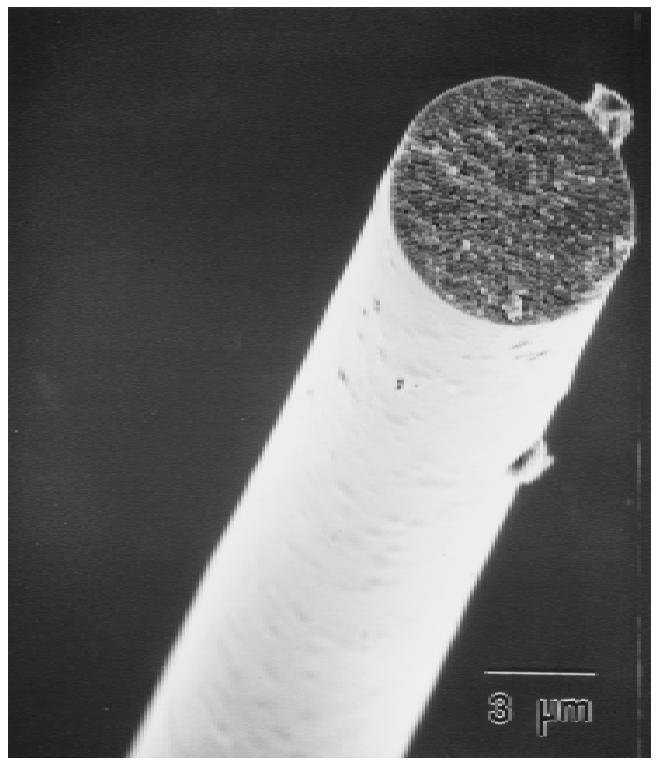

Fig. 16. SEM micrograph of hand-drawn isobutyrate fiber heated to $1000^{\circ} \mathrm{C}$ for $2 \mathrm{~h}$.

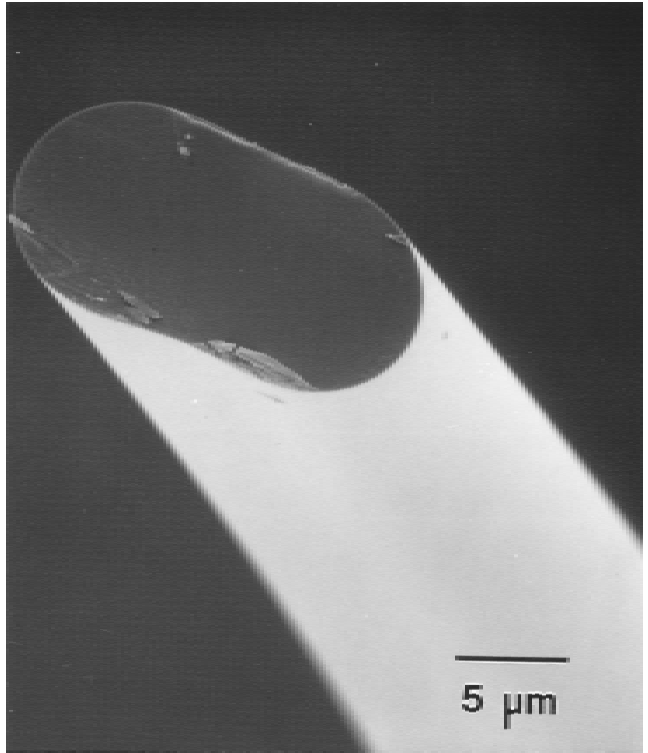

Fig. 17. SEM micrograph of as-spun extruded YAG formate/acetate precursor fiber.

ates the same phase changes in the bulk IR/XRD samples, as observed for the higher-temperature, shorter-time transformations in the DTA. Thus, the exothermic crystallization peak in the DTA occurs at $\sim 1000^{\circ} \mathrm{C}$ rather than the $800^{\circ} \mathrm{C}$ crystallization temperature that has been observed in the XRD studies. Crystallization occurs coincident with the elimination of carbon.

Samples that have been pyrolyzed at $800^{\circ} \mathrm{C} / 1 \mathrm{~h} /$ air are black, and the XRD and DRIFTS analyses both indicate an amorphous material. A sample that has been held for $2 \mathrm{~h}$ at $800^{\circ} \mathrm{C}$ is mostly white, and XRD and DRIFTS analyses reveal crystalline YAG. In the DTA, the air flow is toward the bottom of the sample pan, therefore, no fresh air flows toward the sample directly, and the temperature is ramped continuously, rather than dwelling at a selected temperature for $2 \mathrm{~h}$. Thus, the DTA sample at $895^{\circ} \mathrm{C}$ is still black and amorphous. When the sample is heated further, free carbon is oxidized and eliminated as $\mathrm{CO}_{2}$, and phase transformation occurs. Thus, atmosphere has a

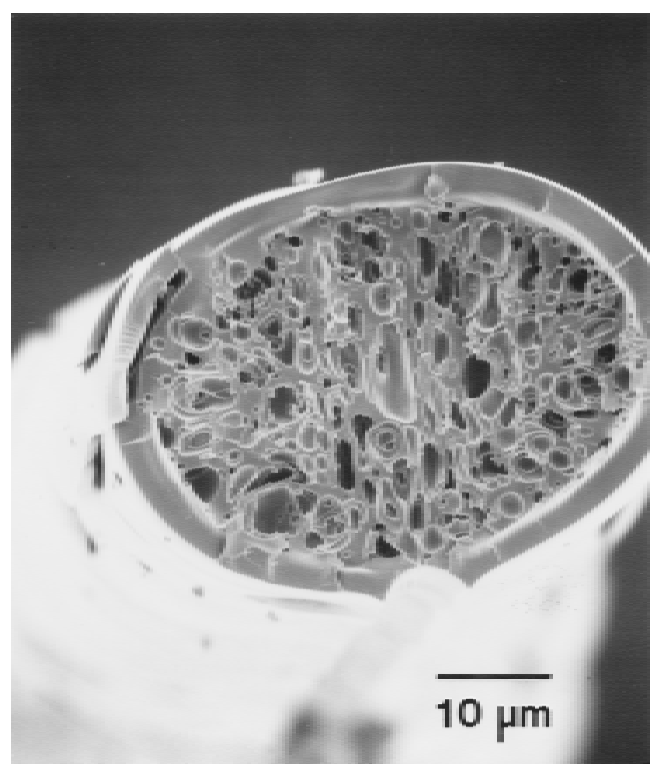

Fig. 18. SEM micrograph of extruded YAG formate/acetate fiber heated at $1^{\circ} \mathrm{C} / \mathrm{min}$ to $100^{\circ} \mathrm{C}$ for $2 \mathrm{~h}$, then to $700^{\circ} \mathrm{C}$ for $2 \mathrm{~h}$. 


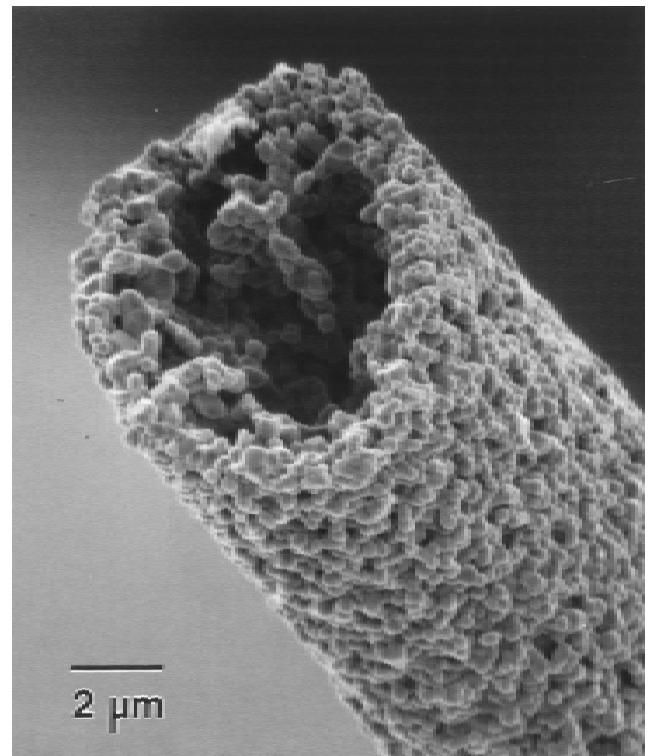

Fig. 19. SEM micrograph of extruded $Y A G$ formate/acetate fiber heated at $1^{\circ} \mathrm{C} / \mathrm{min}$ to $100^{\circ} \mathrm{C}$ for $2 \mathrm{~h}$, then at $20^{\circ} \mathrm{C} / \mathrm{min}$ to $1500^{\circ} \mathrm{C}$ for $2 \mathrm{~h}$.

role in crystallization, because the carbon impurities seem to retard crystallization.

(D) Fiber Processing: To successfully process fully dense, defect-free, polycrystalline YAG fibers, the experimental design must allow for the extreme changes in volume and density that occur as the green precursor fiber transforms to a ceramic fiber. The first step is to clearly define the conditions under which these changes occur by doing bulk material studies. These studies provide an idea of the time/temperature dependence on YAG evolution from precursor and permit the design of a heat-treatment schedule to process dense, carbonfree YAG fibers.

(E) Al/Y Isobutyrate YAG Precursor Fiber Processing: Based on our earlier studies of the $\mathrm{Al} / \mathrm{Y}$ isobutyrate YAG precursor, ${ }^{1}$ YAG isobutyrate precursor fibers were processed by hand drawing and extrusion, followed by pyrolysis. Figure 14

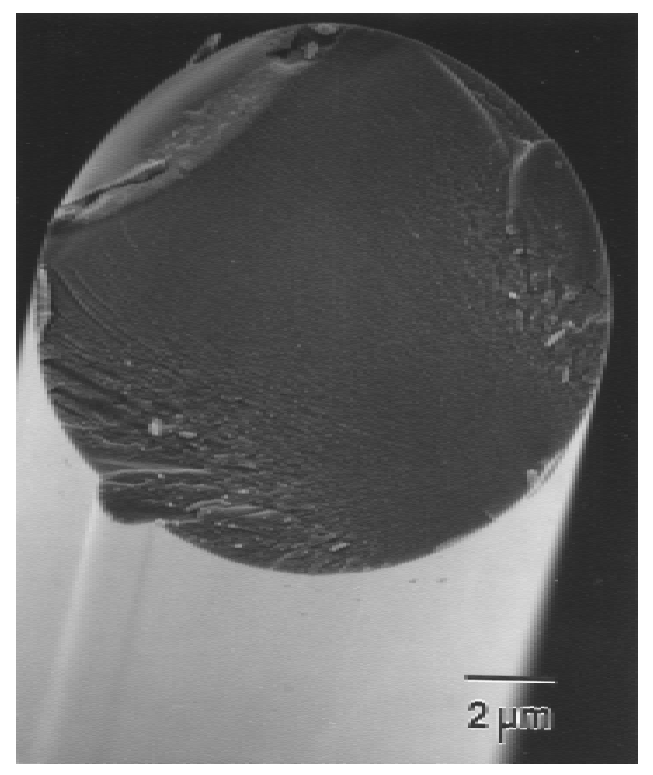

Fig. 20. SEM micrograph of extruded $Y A G$ formate/acetate precursor fiber heated at $1^{\circ} \mathrm{C} / \mathrm{min}$ to $110^{\circ} \mathrm{C}$ for $2 \mathrm{~h}$ and then $1{ }^{\circ} \mathrm{C} / \mathrm{min}$ to $400^{\circ} \mathrm{C}$ for $2 \mathrm{~h}$.

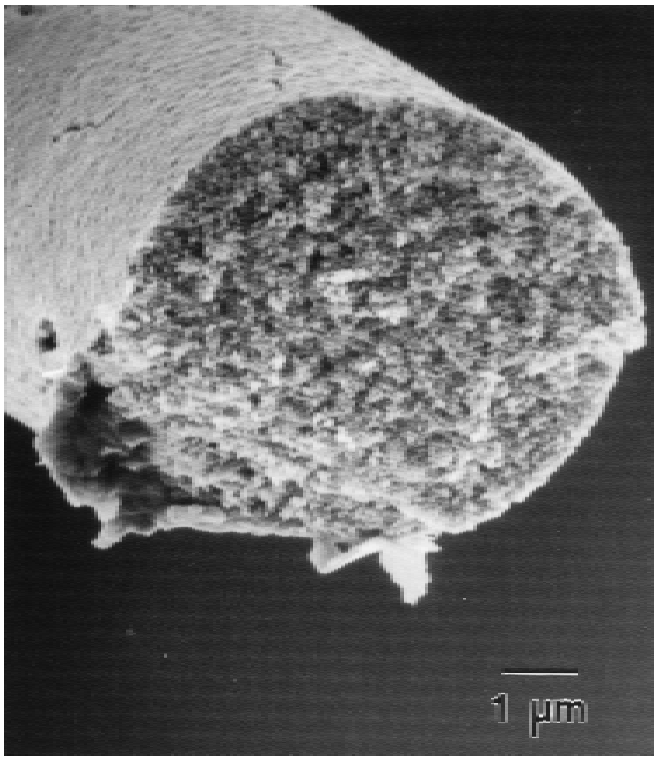

Fig. 21. SEM micrograph of extruded $Y A G$ formate/acetate precursor fiber heated at $1^{\circ} \mathrm{C} / \mathrm{min}$ to $100^{\circ} \mathrm{C}$ for $2 \mathrm{~h}, 1^{\circ} \mathrm{C} / \mathrm{min}$ to $400^{\circ} \mathrm{C}$ for 2 $\mathrm{h}$, and then $15^{\circ} \mathrm{C} / \mathrm{min}$ to $900^{\circ} \mathrm{C}$ for $2 \mathrm{~h}$.

shows an SEM micrograph of an extruded green isobutyrate fiber. The as-processed green fiber has a circular cross section, a smooth surface, and is $70 \mu \mathrm{m}$ in diameter. When the sample is heated to $160^{\circ} \mathrm{C}$, cracks form (Fig. 15). A likely explanation for cracking is that the fiber diameters are too large; thus, the gas diffusion distances are too long. Consequently, gaseous decomposition products accumulate at the subsurface level to form gas bubbles that damage the fibers. For example, a $20 \mathrm{mg}$ precursor $\left(17.5 \mathrm{~mm}^{3}\right)$ releases $2 \mathrm{mg}$ of gaseous byproducts at $200^{\circ} \mathrm{C}$ (the TGA in Fig. 9 shows a $10 \%$ mass loss at $200^{\circ} \mathrm{C}$ ). If the gaseous byproducts are assumed to be either $\mathrm{H}_{2} \mathrm{O}$ or $\mathrm{CO}_{2}$, the generated volume (at room temperature) would be $4.3 \times 10^{3}$ $\mathrm{mm}^{3}$ (for $\mathrm{H}_{2} \mathrm{O}$ ) or $1.8 \times 10^{3} \mathrm{~mm}^{3}$ (for $\mathrm{CO}_{2}$ ). Each volume is a factor of $>100$ greater than the volume of the precursor material.

Based on this consideration, thinner fibers (green-fiber di-

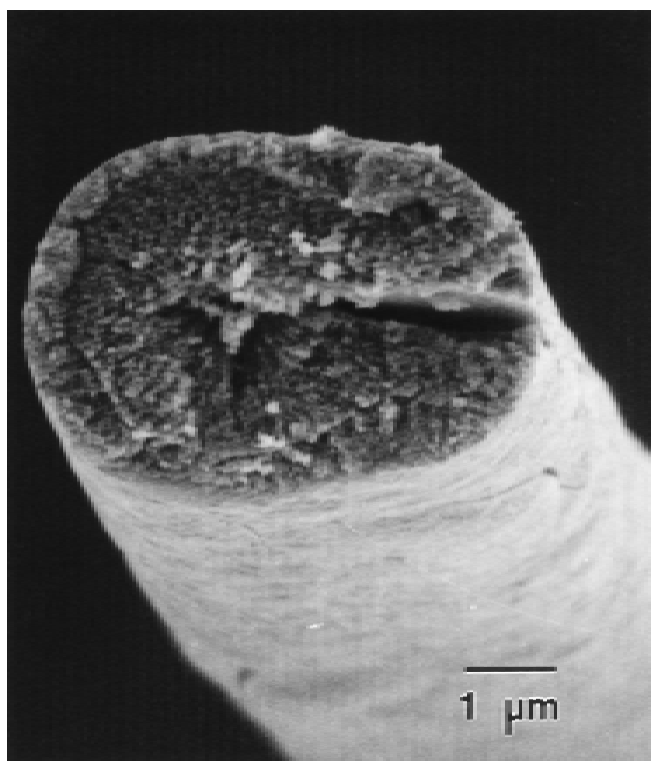

Fig. 22. SEM micrograph of extruded $Y A G$ formate/acetate precursor fiber heated at $1^{\circ} \mathrm{C} / \mathrm{min}$ to $100^{\circ} \mathrm{C}$ for $2 \mathrm{~h}, 1^{\circ} \mathrm{C} / \mathrm{min}$ to $400^{\circ} \mathrm{C}$ for 2 $\mathrm{h}$, and then $15^{\circ} \mathrm{C} / \mathrm{min}$ to $1000^{\circ} \mathrm{C}$ for $2 \mathrm{~h}$. 


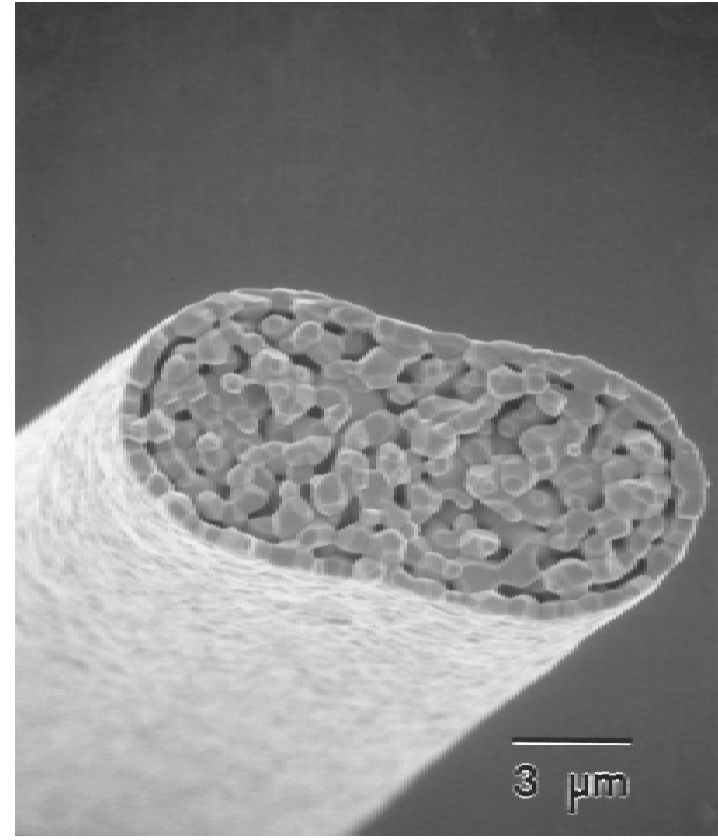

Fig. 23. SEM micrograph of extruded YAG formate/acetate precursor fiber heated at $1^{\circ} \mathrm{C} / \mathrm{min}$ to $100^{\circ} \mathrm{C}$ for $2 \mathrm{~h}, 1^{\circ} \mathrm{C} / \mathrm{min}$ to $400^{\circ} \mathrm{C}$ for 2 h, $15^{\circ} \mathrm{C} / \mathrm{min}$ to $900^{\circ} \mathrm{C}$ for $2 \mathrm{~h}$, and then $15^{\circ} \mathrm{C} / \mathrm{min}$ to $1570^{\circ} \mathrm{C}$ for $2 \mathrm{~h}$.

ameters of $<20 \mu \mathrm{m}$ ) with shorter diffusion distances were made by hand drawing. Thin, crack-free but somewhat porous YAG fibers were obtained by heating to $1000^{\circ} \mathrm{C}$ in air (Fig. 16). Although the fibers are not fully dense, they may still offer useful properties, because their internal porosity is reminiscent of that observed for FP alumina (DuPont, Wilmington, DE) fibers. ${ }^{7,16,38,39}$

\section{(5) Fibers from $\mathrm{Al}\left(\mathrm{O}_{2} \mathrm{CH}\right)_{3} \cdot 3 \mathrm{H}_{2} \mathrm{O}$ and $\mathrm{Y}\left(\mathrm{O}_{2} \mathrm{CCH}_{3}\right)_{3} \cdot 4 \mathrm{H}_{2} \mathrm{O}$}

(A) Density and Volume Changes: The measured density for the YAG precursor is $1.5 \mathrm{~g} / \mathrm{cm}^{3}$, whereas the reported density of YAG is $4.5 \mathrm{~g} / \mathrm{cm}^{3}$. Thus, the theoretical volume change

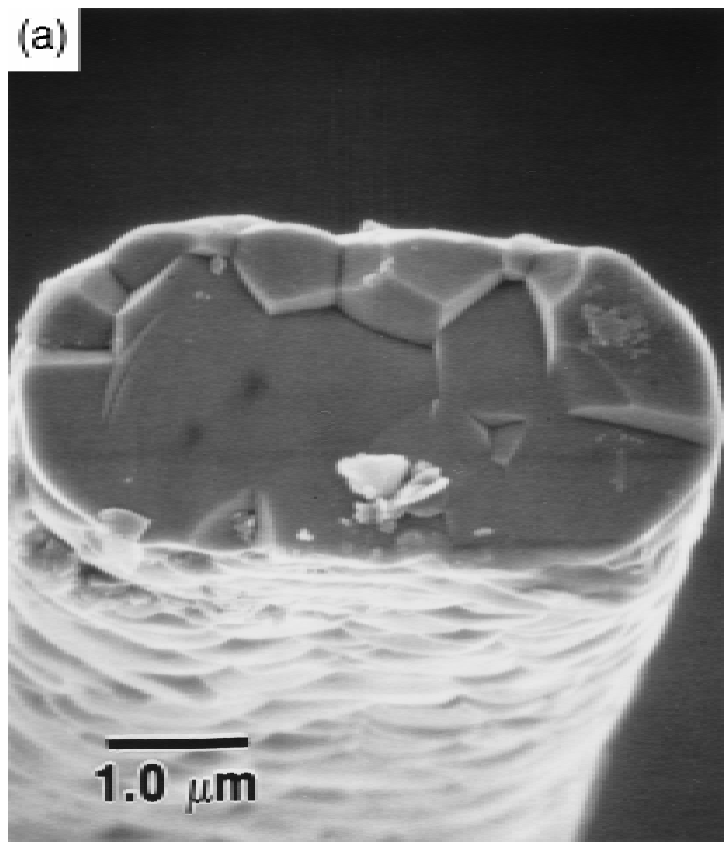

that results from both mass loss and densification is $87 \%$. If we assume that the volume changes that occur as a precursor fiber is pyrolyzed occur only in the diametrical dimension and that full densification results, the expected change in fiber diameter will be $64 \%$. These extensive volume changes must be carefully controlled to ensure that uniform, stress-free ceramic fibers result following pyrolysis.

(B) Green Fiber Processing: As discussed previously, the size (diameter) of the green fiber (Fig. 17) is important to process dense, defect-free YAG fibers. Large-diameter $(>30$ $\mu \mathrm{m})$ green fibers foam or crack during decomposition (e.g., the $40 \mu \mathrm{m}$ diameter fiber in Fig. 18, which was pyrolyzed to $700^{\circ} \mathrm{C} / 2 \mathrm{~h}$ ). The optimum size is $<30 \mu \mathrm{m}$, preferably $<20 \mu \mathrm{m}$ (e.g., as shown in Fig. 17). These acetate formate fibers are easily extruded to give green fibers that are $20 \mu \mathrm{m}$ in diameter and look similar to that shown in Fig. 14. Although the spinneret orifice $(\sim 80 \mu \mathrm{m})$ is circular, extruded green fibers often have a dog-bone cross section, because of uneven drying. Green fibers that have been dried under tension have circular cross sections.

\section{(6) Fiber Pyrolysis}

(A) Low-Temperature Pyrolysis: All fibers were heated at $100^{\circ} \mathrm{C} / 2 \mathrm{~h}$ to remove solvent, water of hydration, and processing aids. Fine green fibers (diameters of $\sim 10 \mu \mathrm{m}$ ) that were pyrolyzed at a rate of $20^{\circ} \mathrm{C} / \mathrm{min}$ directly to $1500^{\circ} \mathrm{C} / 2 \mathrm{~h}$ were porous (Fig. 19). Two factors contribute to the observed porosity. First, with fast heating rates, the surface material decomposes first, which eliminates surface carbonate, and densification/crystallization occurs first at the surface. The interior then gasifies, the pressure builds up, and cracks/flaws form as this gas evolves, which leads to hollow fibers. Second, the fibers do not densify coincident with ligand decomposition. To solve this problem, the fibers were heated at a rate of $1^{\circ} \mathrm{C} / \mathrm{min}$ to $400^{\circ} \mathrm{C} / 2 \mathrm{~h}$, the temperature at which most carboxylates decompose. In this way, the gaseous byproducts diffuse out of the fibers slowly and completely. Fibers that were processed with this heat treatment were dense (see Fig. 20). Consequently, as organics and carbonate in the fiber center decompose, the gaseous byproducts cannot diffuse easily out of the fibers and some voids/internal pores form. To solve this problem, a relatively low heating rate, $10^{\circ} \mathrm{C} / \mathrm{min}$, was selected, and holding

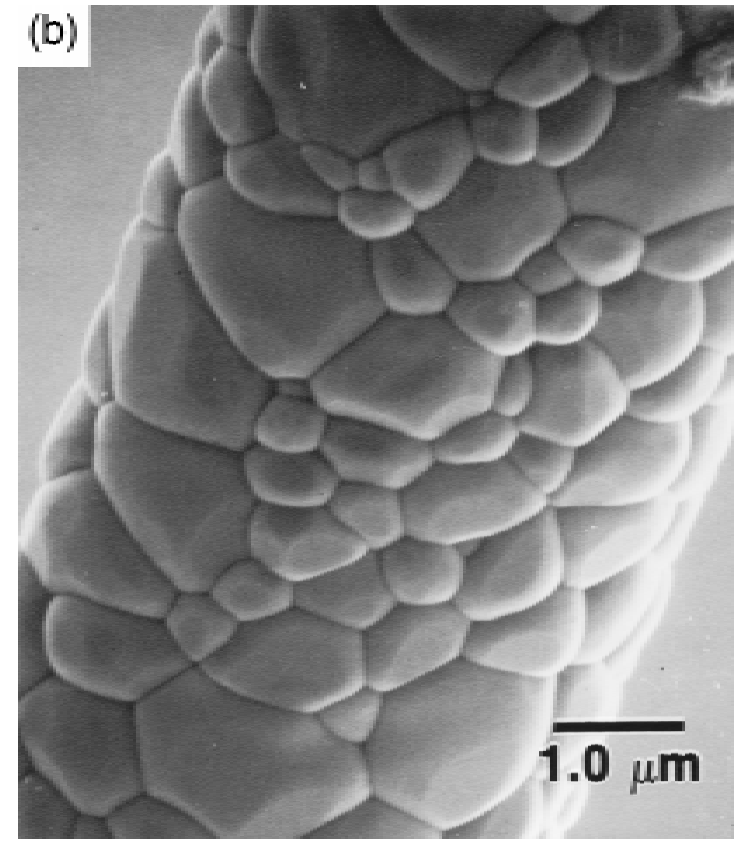

Fig. 24. SEM micrographs of extruded YAG formate/acetate precursor fiber heated at $1^{\circ} \mathrm{C} / \mathrm{min}$ to $100^{\circ} \mathrm{C}$ for $2 \mathrm{~h}, 1^{\circ} \mathrm{C} / \mathrm{min}$ to $400^{\circ} \mathrm{C}$ for $2 \mathrm{~h}$, $15^{\circ} \mathrm{C} / \mathrm{min}$ to $900^{\circ} \mathrm{C}$ for $2 \mathrm{~h}$, and then $30^{\circ} \mathrm{C} / \mathrm{min}$ to $1570^{\circ} \mathrm{C}$ for $2 \mathrm{~h}$. 


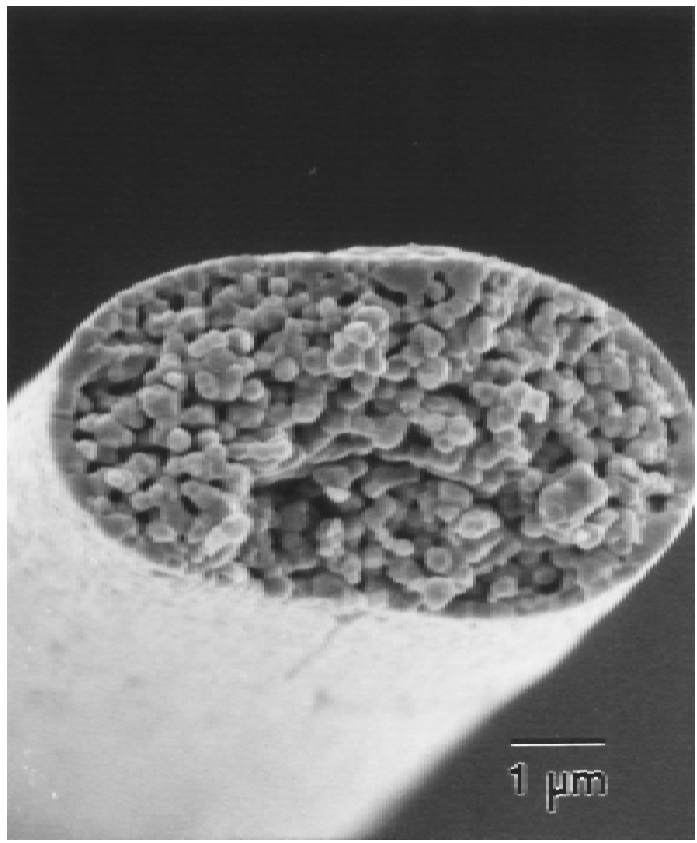

Fig. 25. SEM micrograph of extruded YAG formate/acetate precursor fiber heated at $1^{\circ} \mathrm{C} / \mathrm{min}$ to $100^{\circ} \mathrm{C}$ for $2 \mathrm{~h}, 1^{\circ} \mathrm{C} / \mathrm{min}$ to $400^{\circ} \mathrm{C}$ for 2 h, $15^{\circ} \mathrm{C} / \mathrm{min}$ to $900^{\circ} \mathrm{C}$ for $2 \mathrm{~h}$, and then $30^{\circ} \mathrm{C} / \mathrm{min}$ to $1400^{\circ} \mathrm{C}$ for $2 \mathrm{~h}$.

periods of $2 \mathrm{~h}$ at temperatures of $900^{\circ}$ or $1000^{\circ} \mathrm{C}$ were used to cautiously eliminate carbonate. At these temperatures, YAG grains do not grow dramatically and the fiber surface does not completely densify, as shown in Figs. 21 and 22.

(B) Heating-Rate Studies: Post pyrolysis studies (after heat treatment at $900^{\circ} \mathrm{C}$ ) were conducted to optimize densification and grain growth. Faster heating rates usually result in denser fibers. ${ }^{10 \mathrm{a}}$ For example, $900^{\circ} \mathrm{C}$ fibers that have been heated at a rate of $15^{\circ} \mathrm{C} / \mathrm{min}$ to $1570^{\circ} \mathrm{C}$ for $2 \mathrm{~h}$ are usually porous (Fig. 23), whereas those that have been heated at a rate of $30^{\circ} \mathrm{C} / \mathrm{min}$ to the same temperature are dense (Fig. 24). In addition, a skin seems to form in the fiber shown in Fig. 23. A

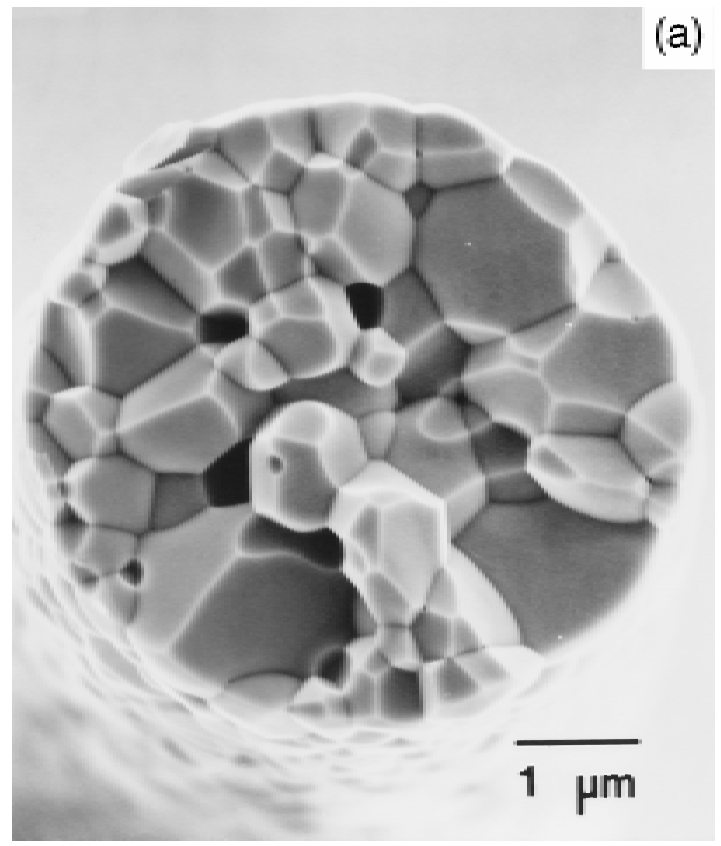

reasonable explanation is that the low heating rate that has been used still promotes more-efficient loss of impurities at the surfaces than in the interior, which results in faster pore coalescence and sintering at the surface than in the interior.

(C) Densification-Temperature Studies: Densification of $900^{\circ} \mathrm{C}$ fibers occurs at $>1400^{\circ} \mathrm{C}$. Figures $25-27$ shows SEM micrographs of the $900^{\circ} \mathrm{C}$ fiber that has been ramped at a rate of $30^{\circ} \mathrm{C} / \mathrm{min}$ to $1400^{\circ}, 1500^{\circ}$, or $1600^{\circ} \mathrm{C}$ for $2 \mathrm{~h}$. Fibers that have been sintered at $1400^{\circ} \mathrm{C}$ for $2 \mathrm{~h}$ exhibit porous cross sections (see Fig. 25). Fibers that have been sintered at $1500^{\circ} \mathrm{C}$ for $2 \mathrm{~h}$ are much denser (Fig. 26), although some voids form at the grain boundaries. Fibers that have been sintered at $1570^{\circ}$ and $1600^{\circ} \mathrm{C}$ for $2 \mathrm{~h}$ are almost fully dense (Figs. 24 and 27).

(D) Mechanical Properties of YAG Fibers: Roomtemperature fiber strength was characterized using a bending test. ${ }^{28,29}$ The bend strength of $900^{\circ} \mathrm{C}$ fibers that have been sintered using post-pyrolysis heat treatments at rates of $30^{\circ} \mathrm{C} /$ min to $1570^{\circ}, 1600^{\circ}$, or $1650^{\circ} \mathrm{C}$ for $2 \mathrm{~h}$ were assessed, as described in the experimental section. At least five fibers were tested for each heating schedule. SEM analysis shows fiber cross sections that are fully dense. For example, the fiber in Fig. $28\left(1570^{\circ} \mathrm{C} / 2 \mathrm{~h}\right)$ has a bend strength of $1.3 \pm 0.3 \mathrm{GPa}$. This calculation is based on the assumption that the fibers that are tested are fully dense, have the same density as bulk material, and have the same elastic modulus $(280 \mathrm{GPa})^{28}$ as bulk material. Figure 29 provides a view of bend strength versus sintering temperature. Based on the results, a $1600^{\circ} \mathrm{C}$ sintering temperature offers the best strength, $1.7 \pm 0.2 \mathrm{GPa}$, with an average grain size of $1.8 \pm 0.2 \mu \mathrm{m}$ (grain sizes were based on pointfraction analysis of SEM micrographs, and at least five fibers were measured for each heating schedule).

When the sintering temperature is $>1600^{\circ} \mathrm{C}$, the grain size increases and reduces the grain-boundary area (Fig. 30), thus reducing the room-temperature strength. Figure 31 plots the bend strength versus the grain size. From the limited amount of data, an average grain size of $1.8 \mu \mathrm{m}$ seems to offer the best strength.

As discussed in the introduction, smaller grain sizes should provide better room-temperature strength if Hall-Petch-type criteria are valid; however, the $1570^{\circ} \mathrm{C}$ fibers with an average grain size of $1.2 \mu \mathrm{m}$ have lower strength. Presently, we cannot explain why $1570^{\circ} \mathrm{C}$ sintering offers lower strength. One pos-

Fig. 26. SEM micrographs of extruded YAG formate/acetate precursor fiber heated at $1^{\circ} \mathrm{C} / \mathrm{min}$ to $100^{\circ} \mathrm{C}$ for $2 \mathrm{~h}, 1^{\circ} \mathrm{C} / \mathrm{min}$ to $400^{\circ} \mathrm{C}$ for $2 \mathrm{~h}$, $15^{\circ} \mathrm{C} / \mathrm{min}$ to $900^{\circ} \mathrm{C}$ for $2 \mathrm{~h}$, and then $30^{\circ} \mathrm{C} / \mathrm{min}$ to $1500^{\circ} \mathrm{C}$ for $2 \mathrm{~h}$. 

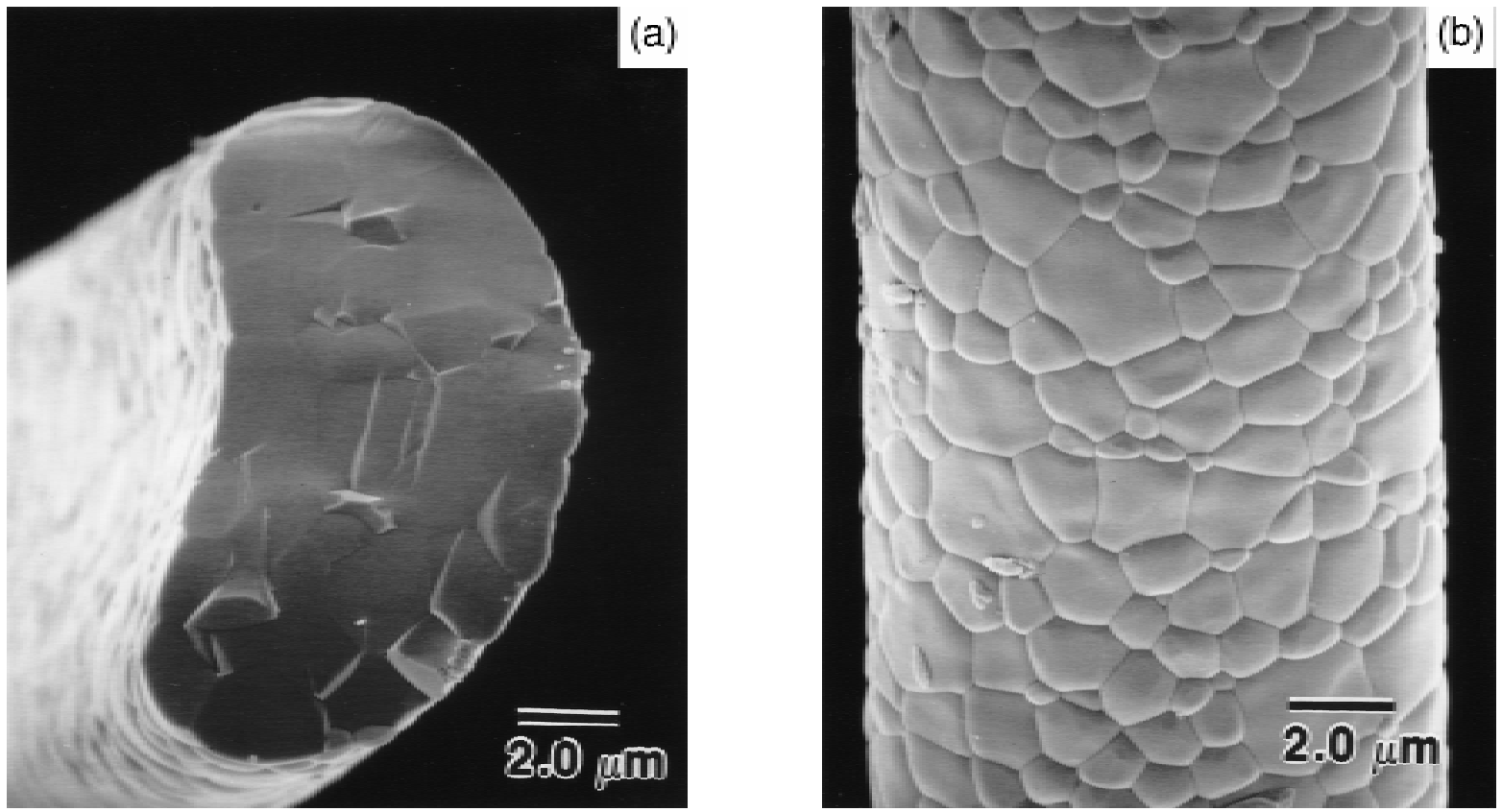

Fig. 27. SEM micrographs of extruded YAG formate/acetate precursor fiber heated at $1^{\circ} \mathrm{C} / \mathrm{min}$ to $100^{\circ} \mathrm{C}$ for $2 \mathrm{~h}, 1^{\circ} \mathrm{C} / \mathrm{min}$ to $400^{\circ} \mathrm{C}$ for $2 \mathrm{~h}$, $15^{\circ} \mathrm{C} / \mathrm{min}$ to $900^{\circ} \mathrm{C}$ for $2 \mathrm{~h}$, and then $30^{\circ} \mathrm{C} / \mathrm{min}$ to $1600^{\circ} \mathrm{C}$ for $2 \mathrm{~h}$.

sible explanation is that, at $1570^{\circ} \mathrm{C}$, the fibers are not completely dense and have a higher flaw population, which leads to bend strengths that are lower than those of $1600^{\circ} \mathrm{C}$ fibers. However, SEM studies on fracture surfaces of fibers that have been sintered at $1570^{\circ} \mathrm{C}$ show porosities of $<0.7 \%$ (pointfraction analysis).

Although pores were not observed at initial fracture positions, we cannot as yet exclude their role as critical flaws. An alternate explanation is that the large, irregular grain boundaries at the fiber surfaces serve as critical flaws. More work

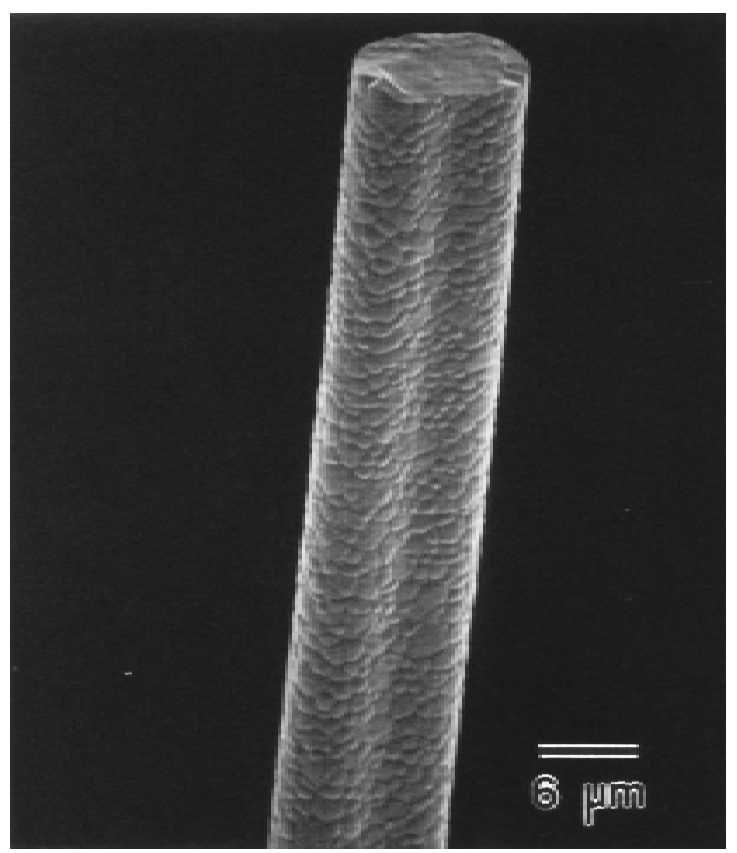

Fig. 28. SEM micrograph of extruded YAG formate/acetate precursor fiber heated at $1^{\circ} \mathrm{C} / \mathrm{min}$ to $100^{\circ} \mathrm{C}$ for $2 \mathrm{~h}, 1^{\circ} \mathrm{C} / \mathrm{min}$ to $400^{\circ} \mathrm{C}$ for 2 h, $15^{\circ} \mathrm{C} / \mathrm{min}$ to $900^{\circ} \mathrm{C}$ for $2 \mathrm{~h}$, and then $30^{\circ} \mathrm{C} / \mathrm{min}$ to $1570^{\circ} \mathrm{C}$ for $2 \mathrm{~h}$; a bending test shows that the fiber has a bend strength of $1.3 \pm 0.2$ GPa. needs to be performed to identify the exact source(s) of failure. Compared to the YAG fibers that were prepared by King et al. ${ }^{10 \mathrm{a}}$ (bend strength of $520 \pm 180 \mathrm{MPa}$ ), thinner YAG fibers with smaller average crystallite sizes seem to offer higher bend strengths $(1.7 \pm 0.2 \mathrm{GPa})$. Additional work is required to fully validate these conclusions and to analyze the creep properties.

\section{Conclusions}

The chemical evolution that occurs during the pyrolytic transformation of bulk samples of $\mathrm{Al}\left(\mathrm{O}_{2} \mathrm{CH}\right)_{3} \cdot 3 \mathrm{H}_{2} \mathrm{O}$ and $\mathrm{Y}\left(\mathrm{O}_{2} \mathrm{CCH}_{3}\right)_{3} \cdot 4 \mathrm{H}_{2} \mathrm{O}$ to their respective, common hightemperature ceramic forms, $\alpha-\mathrm{Al}_{2} \mathrm{O}_{3}$ and bcc $\mathrm{Y}_{2} \mathrm{O}_{3}$, was examined. The results established baseline behavior patterns of use in evaluating the decomposition patterns of a YAG precursor that was formulated from 5:3 stoichiometric mixtures of $\mathrm{Al}\left(\mathrm{O}_{2} \mathrm{CH}\right)_{3} \cdot 3 \mathrm{H}_{2} \mathrm{O}, \mathrm{Y}\left(\mathrm{O}_{2} \mathrm{CCH}_{3}\right)_{3} \cdot 4 \mathrm{H}_{2} \mathrm{O}$, and additives. In the individual cases, decomposition followed well-defined pathways, wherein the initial products were the amorphous oxides that were contaminated with trace-to-minor amounts of the respective carbonates. At higher temperatures, the ceramic

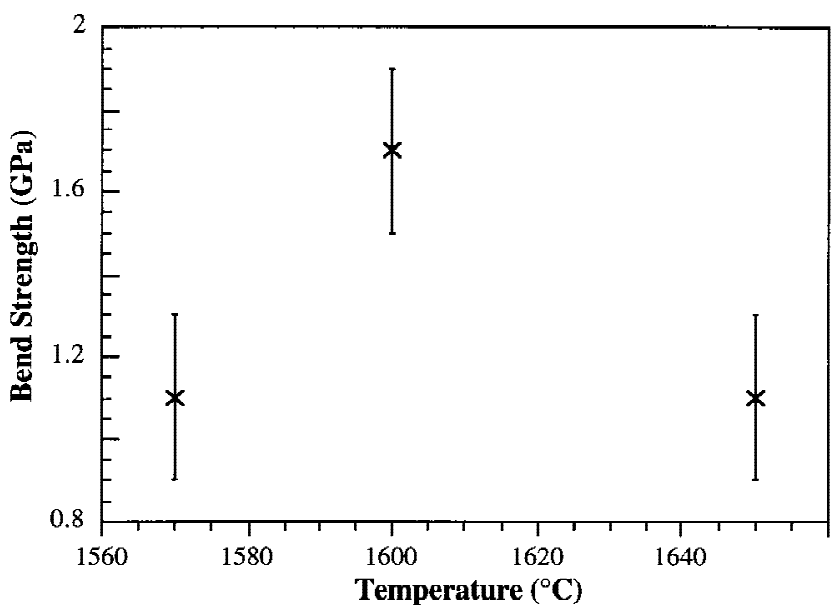

Fig. 29. Bend strength versus sintering temperature. 


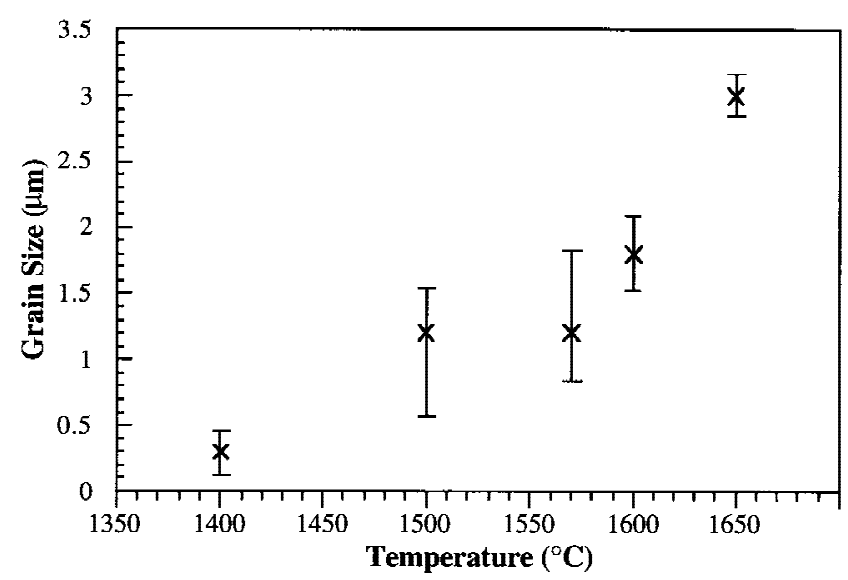

Fig. 30. Grain size versus sintering temperature.

products crystallized: for $\mathrm{Al}\left(\mathrm{O}_{2} \mathrm{CH}\right)_{3} \cdot 3 \mathrm{H}_{2} \mathrm{O}$, first $\eta-\mathrm{Al}_{2} \mathrm{O}_{3}$ $\left(840^{\circ} \mathrm{C}\right)$ and then $\alpha-\mathrm{Al}_{2} \mathrm{O}_{3}\left(>1120^{\circ} \mathrm{C}\right)$; for $\mathrm{Y}\left(\mathrm{O}_{2} \mathrm{CCH}_{3}\right)_{3} \cdot 4 \mathrm{H}_{2} \mathrm{O}$, only bcc $\mathrm{Y}_{2} \mathrm{O}_{3}\left(\geq 400^{\circ} \mathrm{C}\right)$. Surprisingly, these results had almost no bearing on the reactivity pattern of the YAG precursor, which behaved like a separate compound and decomposed to crystalline $\mathrm{YAG}$ at $\sim 800^{\circ} \mathrm{C}$ without any phase separation.

Finally, isobutyrate and acetate/formate YAG precursors were both easily spun or hand drawn to form well-defined green fibers. The thicker extruded fibers exhibited excessive cracking and foaming when efforts were made to form ceramic fibers, which can be attributed to the subsurface buildup of gases during the conversion process. Thinner green fibers $(<30$ $\mu \mathrm{m})$ are easily converted to fully dense ceramic fibers at temperatures $\geq 1570^{\circ} \mathrm{C}$. The best bend strength for these fibers is $1.7 \pm 0.2 \mathrm{GPa}\left(1600^{\circ} \mathrm{C}\right.$ sintering), which is a factor of $\sim 3$ greater than that found for polycrystalline YAG fibers in previous studies.

\section{References}

${ }^{1}$ Y. Liu, Z.-F. Zhang, B. King, J. W. Halloran, and R. M. Laine, "Synthesis of Yttrium Aluminum Garnet from Yttrium and Aluminum Isobutyrate Precursors,"' J. Am. Ceram. Soc., 79 [2] 385-94 (1996).

${ }^{2}$ (a) G. S. Corman, "High-Temperature Creep of Some Single Crystal Oxides," Ceram. Eng. Sci. Proc., 12 [9-10] 1745-66 (1991). (b) T. A. Parthasarathy, T. Mah, and K. Keller, "High-Temperature Deformation Behavior of Polycrystalline Yttrium Aluminum Garnet (YAG),' Ceram. Eng. Sci. Proc., 12 [9-10] 1767-73 (1991).

${ }^{3}$ E. M. Levin, C. R. Robbins, and H. F. McMurdie, Phase Diagrams for Ceramists; p. 122. American Ceramic Society, Columbus, OH, 1969.

${ }^{4}$ A. H. Chokshi and J. R. Porter, "Analysis of Concurrent Grain Growth During Creep of Polycrystalline Alumina," J. Am. Ceram. Soc., 69 [2] C-37C-39 (1986).

${ }^{5}$ D. Hull, An Introduction to Composite Materials; pp. 1-8. Edited by R. W. Cahn, E. A. Davis, and I. M. Ward. Cambridge University Press, Cambridge, U.K., 1985.

${ }^{6}$ (a) F. T. Wallenberger, N. E. Weston, and S. A. Dunn, "Inviscid Melt Spinning: As-Spun Crystalline Alumina Fibers,"' J. Mater. Res., 5 [11] 2682-86 (1990). (b) F. T. Wallenberger, N. E. Weston, K. Motzfeldt, and D. G. Swartzfager, "Inviscid Melt Spinning of Alumina Fibers: Chemical Jet Stabilization,' J. Am. Ceram. Soc., 75 [3] 629-36 (1992). (c) F. T. Wallenberger, "Melt Spinning of Amorphous Alumina Fibers," Am. Ceram. Soc. Bull., 69 [10] 1646-48 (1990).

${ }^{7}$ T. F. Cooke, "Inorganic Fibers-A Literature Review,"' J. Am. Ceram. Soc., 74 [12] 2959-78 (1991).

${ }^{8}$ L. E. Seulert, “Alumina Fiber,’ U.S. Pat. No. 3808 015, 1974.

${ }^{9}$ Z.-F. Zhang, "Processing Silicon Carbide Fibers from Organosilicon Precursors"'; Ph.D. Dissertation. The University of Michigan, Ann Arbor, MI, 1994.

${ }^{10}$ (a) B. H. King, Y. Liu, R. M. Laine, and J. W. Halloran, "Fabrication of Yttrium Aluminate Fibers," Ceram. Eng. Sci. Proc., 14 [7-8] 639-50 (1993). (b) S. D. Nunn, D. Popovic, S. Baskaran, J. W. Halloran, G. Subramanian, and S. G. Bike, "Suspension Dry Spinning and Rheological Behavior of CeramicPowder-Loaded Polymer Solutions," J. Am. Ceram. Soc., 76 [10] 2460-64 (1993).

${ }^{11}$ G. Gowda, "Synthesis of Yttrium Aluminates by the Sol-Gel Process," J. Mater. Sci. Lett., 5, 1029-32 (1986).

${ }^{12}$ (a) R. M. Laine, K. A. Youngdahl, R. A. Kennish, M. L. Hoppe, Z.-F. Zhang, and D. J. Ray, "Superconducting Fibers from Organometallic Precursors, Part II: Chemistry and Low Temperature Processing,' J. Mater. Res., 6,

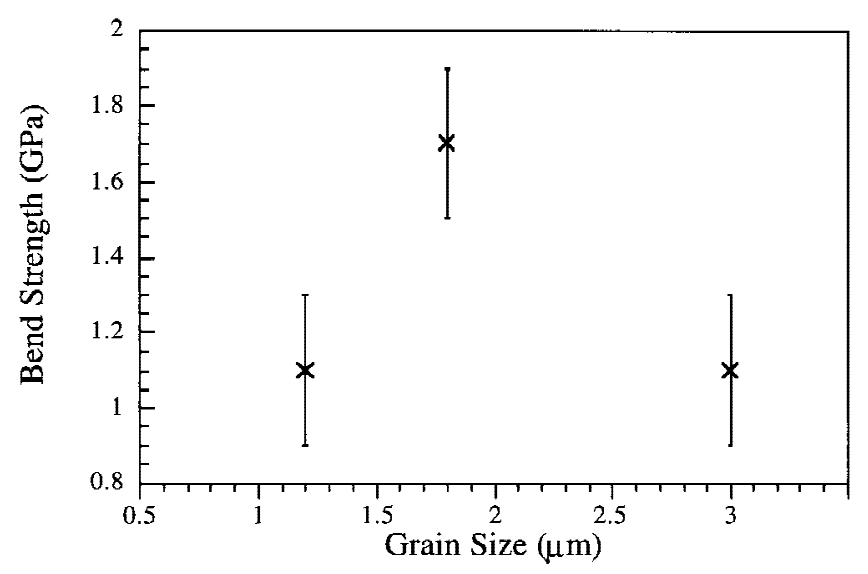

Fig. 31. Bend strength versus grain size.

895 (1991). (b) Z.-F. Zhang, R. A. Kennish, K. A. Blohowiak, M. L. Hoppe, and R. M. Laine, "Superconducting Fibers From Organometallic Precursors. Part III. High Temperature Pyrolytic Processing,' J. Mater. Res., 8, 1777-90 (1993). (c) R. M. Laine and K. A. Youngdahl, U.S. Pat. No. 5071 833, 1993.

${ }^{13}$ R. S. Hay, "Phase Transformations and Microstructure Evolution in SolGel Derived Yttrium-Aluminum Garnet Films,'” J. Mater. Res., 8, 578-604 (1993).

${ }^{14}$ R. Baranwal, A. Zika, B. L. Mueller, and R. M. Laine, 'Preceramic Polymer Routes to Amorphous and Crystalline Aluminosilicate Powders for Electrorheological Applications. I.' ; pp. 157-69 in Progress in Electrorheology. Edited by K. Havelka and F. E. Filisko. Plenum Press, New York, 1995.

${ }^{15}$ (a)S. Yajima, "Synthesis of a Polytitanocarbosilane and Its Conversion into Inorganic Compounds,' J. Mater. Sci., 16, 1349-55 (1981). (b) S. Yajima, "Special Heat-Resisting Materials from Organometallic Polymers," Am. Ceram. Soc. Bull., 62 [8] 893-98 (1983).

${ }^{16}$ J. C. Romine, "Aluminum Oxide Fibers"; pp. 151-75 in Handbook of Fiber Science and Technology: Vol. III, High Technology Fibers Part B. Edited by M. Lewin and J. Preston. Marcel Dekker, New York, 1983.

${ }^{17}$ Sumitomo Chemical Industries, Jpn. Pat. Nos., 8398428 and 5898428 , 1983.

${ }^{18}$ D. D. Johnson, J. Coated Fabr., 11, 282 (1981).

${ }^{19}$ G. F. Everitt, "Stabilized Aluminum Acetate Used for an Alumina Source in Ceramic Fibers', ; in Ultrastructure Processing of Advanced Ceramics. Edited by J. D. Mackenzie and D. R. Ulrich. Wiley, New York, 1988.

${ }^{20}$ H. G. Sowman and T. T. Tran, "Refractory Fibers of Alumina and Amorphous Phosphorus Pentoxide,' U.S. Pat. No. 4801 562, 1989.

${ }^{21}$ T. E. Wood and D. M. Wilson, "Microcrystalline Alumina-Based Ceramic Articles," U.S. Pat. No. 4954 462, 1990.

${ }^{22}$ (a) H. G. Sowman, "Refractory Fibers of Alumina and Organic Residue," U.S. Pat. No. 4929 578, 1990. (b) D. M. Wilson, D. C. Lueneburg, and S. L. Lieder, "High Temperature Properties of Nextel 610 and Alumina-Based Nanocomposite Fibers," Ceram. Eng. Sci. Proc., 14 [7-8] 609-21 (1993).

${ }^{23}$ (a) K. Pallavi; unpublished paper on mullite fibers. (b) G. D. Soraru, M. Mercadini, R. D. Maschio, F. Taulelle, and F. Babonneau, "Si-Al-O-N Fibers from Polymeric Precursor: Synthesis, Structural, and Mechanical Characterization," J. Am. Ceram. Soc., 76 [10] 2595-600 (1993). (c) O. Funayama, H. Nakahara, A. Tezuka, T. Ishii, and T. Isoda, "Development of Si-B-O-N Fibers from Polyborosilazane,'” J. Mater. Sci., 29, 2238-44 (1994). (d) D. B. Marshall, F. F. Lange, and P. D. Morgan, "High-Strength Zirconia Fibers," J. Am. Ceram. Soc., 70 [8] C-187-C-188 (1987). (e) M. E. P. Fernandez, C. Kang, and P. L. Mangonon, 'Processing Ceramic Fibers by Sol-Gel,' Chem. Eng. Prog., 89 [9] 49-53 (1993). (f) G. Emig, R. Wirth, and R. Zimmermann-Chopin, "Sol/Gel-Based Precursors for Manufacturing Refractory Oxide Fibers," $J$. Mater. Sci., 29, 4559-66 (1994).

${ }^{24}$ (a) J. Yang, S. M. Jeng, and S. Chang, "Fracture Behavior of Directionally Solidified $\mathrm{Y}_{3} \mathrm{Al}_{5} \mathrm{O}_{12} / \mathrm{Al}_{2} \mathrm{O}_{3}$ Eutectic Fiber,' J. Am. Ceram. Soc., 79 [5] 1218-22 (1996). (b) T. Mah, T. A. Parthasarathy, and L. E. Matson, "Processing and Properties of $\mathrm{Al}_{2} \mathrm{O}_{3} / \mathrm{Y}_{3} \mathrm{Al}_{5} \mathrm{O}_{12}$ (YAG) Eutectic Composite,' Ceram. Eng. Sci. Proc., 11 [9-10] 1617 (1990).

25 (a) B. M. Tissue, W. Jia, L. Lu, and W. M. Yen, "Coloration of ChromiumDoped Yttrium Aluminum Garnet Single-Crystal Fibers Using a Divalent Codopant," J. Appl. Phys., 70 [7] 3775-77 (1991). (b) G. S. Corman, "Strength and Creep of Single Crystal YAG Fibers"; presented at the 94th Annual Meeting of the American Ceramic Society, Minneapolis, MN, April 12-16, 1992 (Paper No. 64-SII-92).

${ }^{26} \mathrm{G}$. N. Morscher, K. C. Chen, and K. S. Mazdiyasni, "Creep-Resistance of Developmental Polycrystalline Yttrium-Aluminum Garnet Fibers,' Ceram. Eng. Sci. Proc., 14 [7-8] 181-88 (1994).

${ }^{27}$ Y. Liu, B. H. King, Z.-F. Zhang, J. W. Halloran, and R. M. Laine, "Creep Resistant Oxide Fibers,' Paper No. WL-TR-94-4100, Materials Directorate, Wright Laboratory, Air Force Material Command, Wright-Patterson AFB, OH, March 1994.

${ }^{28}$ B. H. King and J. W. Halloran, "Polycrystalline Yttrium Aluminum Garnet Fibers from Colloidal Sols,' J. Am. Ceram. Soc., 78 [8] 2141-48 (1995). 
${ }^{29}$ P. A. Siemers, R. L. Mehan, and H. Moran, "A Comparison of the Uniaxial Tensile and Pure Bending Strength of SiC Filaments," J. Mater. Sci., 23, 1329-33 (1988).

${ }^{30}$ J. T. Kwon, "Aluminum Formate: Part I, The Synthesis of Aluminum Formates. Part II, The Pyrolysis Reactions of Aluminum Formates"; Ph.D Dissertation; pp. 9-19. Cornell University, New York, 1963.

${ }^{31}$ N. M. Chaplygina, I. Z. Babievskaya, and I. B. Kudinov, "Preparation and Physicochemical Properties of $\mathrm{Al}(\mathrm{HCOO})_{3} \cdot 3 \mathrm{H}_{2} \mathrm{O}$,' Russ. J. Inorg. Chem. (Engl. Transl.), 29 [9] 1260-63 (1984).

${ }^{32}$ T. Sato, "Thermal Decomposition of Inorganic and Organic Acid Salts of Aluminum and Thermal Transformation of the Formed Aluminas," Netsu Sokutei, 13 [3] 113-22 (1986).

${ }^{33}$ L. M. Seaverson, S.-Q. Luo, P.-L. Chien and J. F. McClelland, " Carbonate Associated with Hydroxide Sol-Gel Processing of Yttria: An Infrared Spectroscopic Study," J. Am. Ceram. Soc., 69 [5] 423-29 (1986).
${ }^{34}$ G. A. M. Hussein, "Formation of High Surface-Area Yttrium Oxide by the Thermal Decomposition of Different Inorganic Precursors,' Thermochim. Acta, 244, 139-51 (1994).

${ }^{35}$ V. N. Maksimov, K. N. Semenenko, T. N. Naumova, and A. V. Novoselova, “The Aluminum Acetates,"' Russ. J. Inorg. Chem. (Engl. Transl.), 5 [3] 267-70 (1960).

${ }^{36}$ W. Weng, J. Yang, and Z. Ding, "The Sol-Gel Process of the Yttrium Complex from Yttrium Acetate,' J. Non-Cryst. Solids, 169, 177-82 (1994).

${ }^{37}$ P. Apte, H. Burke, and H. Pickup, "Synthesis of Yttrium Aluminum Garnet by Reverse Strike Precipitation," J. Mater. Res., 7 [3] 706-11 (1992).

${ }^{38}$ V. Lavaste, J. Besson, M. Berger, and A. R. Bunsell, "Elastic and Creep Properties of Alumina-Based Single Fibers,'” J. Am. Ceram. Soc., 78 [11] 308187 (1995)

${ }^{39}$ D. J. Pysher and R. E. Tressler, "Creep Rupture Studies of Two AluminaBased Ceramic Fibers,'” J. Mater. Sci., 27, 423-28 (1992). 